\title{
Enhancement of Macrophage Function by the Antimicrobial Peptide Sublancin Protects Mice from Methicillin-Resistant Staphylococcus aureus
}

\author{
Shuai Wang, ${ }^{1,2}$ Qianhong Ye, ${ }^{1}$ Ke Wang, ${ }^{3}$ Xiangfang Zeng, ${ }^{1}$ Shuo Huang, ${ }^{1}$ Haitao Yu, \\ Qing Ge, ${ }^{3}$ Desheng $\mathbf{Q i}^{2}$ and Shiyan Qiao ${ }^{1}{ }^{1}$ \\ ${ }^{1}$ State Key Laboratory of Animal Nutrition, Beijing Key Laboratory of Biofeed Additives, Ministry of Agriculture Feed \\ Industry Center, China Agricultural University, Beijing 100193, China \\ ${ }^{2}$ Department of Animal Nutrition and Feed Science, College of Animal Science and Technology, Huazhong Agricultural University, \\ Wuhan, Hubei 430070, China \\ ${ }^{3}$ Key Laboratory of Medical Immunology, Ministry of Health, Department of Immunology, School of Basic Medical Sciences, \\ Peking University Health Science Center, Beijing 100191, China
}

Correspondence should be addressed to Shiyan Qiao; qiaoshiyan@cau.edu.cn

Received 31 May 2019; Accepted 2 August 2019; Published 8 September 2019

Guest Editor: Pedro A. Reche

Copyright (C) 2019 Shuai Wang et al. This is an open access article distributed under the Creative Commons Attribution License, which permits unrestricted use, distribution, and reproduction in any medium, provided the original work is properly cited.

\begin{abstract}
Methicillin-resistant Staphylococcus aureus (MRSA) is the major pathogen responsible for community and hospital bacterial infections. Sublancin, a glucosylated antimicrobial peptide isolated from Bacillus subtilis 168, possesses antibacterial infective effects. In this study, we investigated the role and anti-infection mechanism of sublancin in a mouse model of MRSA-induced sublethal infection. Sublancin could modulate innate immunity by inducing the production of IL- $1 \beta$, IL-6, TNF- $\alpha$, and nitric oxide, enhancing phagocytosis and MRSA-killing activity in both RAW264.7 cells and mouse peritoneal macrophages. The enhanced macrophage function by the peptide in vitro correlated with stronger protective activity in vivo in the MRSA-invasive sublethal infection model. Macrophage activation by sublancin was found to be partly dependent on TLR4 and the NF- $\kappa \mathrm{B}$ and MAPK signaling pathways. Moreover, oral administration of sublancin increased the frequencies of $\mathrm{CD}^{4+}$ and $\mathrm{CD}^{8+} \mathrm{T}$ cells in mesenteric lymph nodes. The protective activity of sublancin was associated with in vivo augmenting phagocytic activity of peritoneal macrophages and partly improving $\mathrm{T}$ cell-mediated immunity. Macrophages thus represent a potentially pivotal and novel target for future development of innate defense regulator therapeutics against $S$. aureus infection.
\end{abstract}

\section{Introduction}

Concurrent with the success of antibiotics for treating infections, their excessive use contributes to the emergence of antibiotic-resistant bacteria [1]. Methicillin-resistant Staphylococcus aureus (MRSA) is widespread and multiresistant; thus, it has challenged the effectiveness of antibiotics including $\beta$-lactams, macrolides, and quinolones, as well as vancomycin which has been accepted as the first-line option for treating infections due to MRSA [2]. Antibiotic resistance has become an increasingly serious health care problem in the world [3]. This has been aggravated by a collapse in the number of approvals of new antibacterials in the past three decades [4].

Macrophages are professional phagocytes of the innate immune system, providing a first line of defense against infections. It has been reported that macrophages play an important role in the clearance of $S$. aureus in the infected mice [5]. Mice that have been depleted of macrophages are susceptible to MRSA infection [6]. Nevertheless, some investigators have pointed out several characteristics of MRSA that may enable it to thwart the macrophage-mediated host defense [7]. Macrophages can kill bacteria directly through phagocytosis and indirectly via releasing inflammatory 
molecules and nitric oxide (NO), as well as by secreting proinflammatory factors, such as interleukin-6 (IL-6), IL-1 $\beta$, and tumor necrosis factor- $\alpha$ (TNF- $\alpha)[8,9]$. Macrophages are the first immune cells that are recruited to the infection site, and they are the main source of proinflammatory cytokines after activation [10]. Many investigators have reported that progressing macrophage dysfunction may contribute to severe sepsis $[11,12]$.

Antimicrobial peptides (AMPs) are important components of the innate immune defense against a wide range of invading pathogens $[13,14]$. Sublancin is a 37 -amino-acid AMP isolated from the Gram-positive soil bacterium Bacillus subtilis 168 [15]. It is not a lantibiotic but rather a very unusual S-linked glycopeptide [16]. Sublancin contains two $\alpha$-helices and a well-defined interhelical loop connected by a S-glucosidic linkage to a Cys [17]. Mature sublancin has a molecular mass of $3879.8 \mathrm{Da}$ [18]. In our previous studies, we showed that sublancin was protective in several in vivo infection models. Although the minimum inhibitory concentration (MIC) of sublancin was much higher than that of traditional antibiotics in vitro, it was demonstrated that sublancin was effective against Clostridium perfringens-induced necrotic enteritis in broilers [19]. We also found that sublancin has potential for the prevention of $S$. aureus infection in mice [18]. Moreover, sublancin was further found to protect against drug-resistant bacteria in a mouse MRSA infection model [20]. Several reports have demonstrated that AMPs were capable of activating macrophage function [13, 21]. Recently, we revealed the capability of sublancin in activating macrophages and improving the innate immunity of mice in vivo [22]. Hence, the goal of the present study was to explore the potential anti-infection mechanism of this peptide. In the present study, we investigated whether sublancin can (i) activate macrophages and the signaling pathway involved in this process, (ii) inhibit bacterial growth in a model of MRSA-infected mice and macrophages, and (iii) improve immune function in mice under healthy and MRSA-induced sublethal infection conditions.

\section{Materials and Methods}

2.1. Mice, Cell Lines, Peritoneal Macrophages, and Chemicals. Female BALB/c mice were used for the experiments. The murine macrophage cell line RAW264.7 was obtained from China Infrastructure of Cell Line Resource (Beijing, China) and maintained in Dulbecco's Modified Eagle's Medium (DMEM) (Gibco) containing 10\% fetal bovine serum (Life Technologies). Peritoneal macrophages (P-Mac) were isolated from BALB/c mice as previously described [23]. Briefly, mice were intraperitoneally injected with $2 \mathrm{ml} 4 \%$ thioglycollate. Three days after injection, peritoneal exudate cells were harvested by lavaging the peritoneal cavity with sterile icecold Hank's balanced salt solution (HBSS) (Gibco, Life Technologies). These cells were incubated for $2 \mathrm{~h}$, and adherent cells were used as peritoneal macrophages. Sublancin was generated in our laboratory using a highly efficient expression system involving Bacillus subtilis 800 as described previously [18]. The purity of this peptide was above $99.6 \%$ as determined by high-performance liquid chromatography.
Sublancin was produced as lyophilized powder, and the endotoxin concentration of the peptide was less than $0.05 \mathrm{EU} / \mathrm{mg}$, as detected by the E-Toxate Kit (SigmaAldrich). Sublancin was resuspended in endotoxin-free water (Sigma-Aldrich) and stored at $-20^{\circ} \mathrm{C}$. All reagents used in this study were tested for endotoxin to eliminate the interference of endotoxin contamination.

2.2. Cytokine Assays. The culture supernatants of RAW264.7 cells or mouse peritoneal macrophages treated with sublancin $(25,50,100$, or $200 \mu \mathrm{M})$ for $24 \mathrm{~h}$ were collected for the detection of IL- $1 \beta$, IL- 6 , and TNF- $\alpha$ levels using commercially available cytometric bead arrays (BD Biosciences) according to the protocol of the manufacturer. Data were acquired with a FACSCalibur flow cytometer and analyzed with BD CBA Software (BD Biosciences).

2.3. NO Production. The nitrite accumulated in the culture medium was determined by Griess reaction. RAW264.7 cells or mouse peritoneal macrophages were treated with various concentrations of sublancin $(25,50,100$, or $200 \mu \mathrm{M})$. After $24 \mathrm{~h}$, culture supernatants were mixed with an equal volume of Griess reagent ( $1 \%$ sulfanilamide, $0.1 \% \mathrm{~N}$-1-naphthylenediamine dihydrochloride in $2.5 \%$ phosphoric acid) and incubated at room temperature for $10 \mathrm{~min}$. The absorbance was detected at $540 \mathrm{~nm}$, and NO concentration was determined from a calibration curve of standard sodium nitrite concentrations against absorbance.

2.4. Quantitative Real-Time PCR. To detect the effect of sublancin on gene expression, RAW264.7 cells or mouse peritoneal macrophages $\left(1 \times 10^{6}\right.$ cells/well $)$ were preincubated on 6 -well plates and treated with sublancin $(25,50,100$, or 200 $\mu \mathrm{M})$ for $12 \mathrm{~h}$ at $37^{\circ} \mathrm{C}$ in an atmosphere containing $5 \% \mathrm{CO}_{2}$. Total RNA were isolated using a RNeasy Mini Kit (Qiagen, Hilden, Germany). The quality and quantity of total RNA were determined by gel electrophoresis and a NanoDrop Spectrophotometer (Implen NanoPhotometer P330, Germany). cDNA was synthesized from the extracted RNA (1 $\mu \mathrm{g})$ using a PrimeScript 1st Strand cDNA Synthesis Kit (Takara Bio Inc., Otsu, Japan) according to the manufacturer's protocol. Real-time PCR was performed on an Applied Biosystems 7500 Real-Time PCR System (Applied Biosystems, Singapore) with the SYBR Green PCR Master Mix (Takara Bio Inc., Otsu, Japan). The PCR system contained 5.0 $\mu \mathrm{l}$ of SYBR Green qPCR Mix, $1.0 \mu \mathrm{l}$ of cDNA, $0.4 \mu \mathrm{l}$ of primer pairs ( $25 \mu \mathrm{M}$ forward and $25 \mu \mathrm{M}$ reverse), and $3.6 \mu \mathrm{l}$ doubledistilled water in a final volume of $10 \mu \mathrm{l}$. The protocols for all genes included a denaturation program $\left(1 \mathrm{~min}\right.$ at $\left.95^{\circ} \mathrm{C}\right)$ and an amplification and quantification program repeated for 40 cycles $\left(5 \mathrm{~s}\right.$ at $95^{\circ} \mathrm{C}, 30 \mathrm{~s}$ at $60^{\circ} \mathrm{C}$ ), followed by the melting curve program at $60-95^{\circ} \mathrm{C}$ with a heating rate of $0.1^{\circ} \mathrm{C}$ per second and continuous fluorescence measurement. Relative gene expression data were normalized against GAPDH and analyzed using the $2^{-\Delta \Delta \mathrm{Ct}}$ method [24]. Primers for the selected genes are given in Table $\mathrm{S} 1$.

2.5. Measurement of Phagocytic Uptake. RAW264.7 cells $\left(1 \times 10^{6}\right.$ cells/well $)$ or mouse peritoneal macrophages were cultured in 6-well plates until $80 \%$ confluent. The cells were 
treated with various concentrations of sublancin $(25,50,100$, or $200 \mu \mathrm{M}$ ) for $12 \mathrm{~h}$. Thereafter, $100 \mu \mathrm{l}$ of suspended fluorescent microspheres in PBS was added to the wells (cells to beads ratio $1: 20$ ) and the cells were incubated at $37^{\circ} \mathrm{C}$ for $1 \mathrm{~h}$. Phagocytosis was terminated by the addition of $2 \mathrm{ml}$ of ice-cold PBS, and then the cells were washed three times with cold PBS and harvested. Flow cytometric analysis was performed using a FACSCalibur flow cytometer using BD CellQuest software (BD Biosciences, San Jose, CA, USA).

2.6. Determination of Macrophage MRSA-Killing Activity. MRSA ATCC43300, obtained from the American Type Culture Collection (Manassas, VA), were grown overnight at $37^{\circ} \mathrm{C}$ in $\mathrm{LB}$ broth, washed in PBS, and adjusted to $10^{7} \mathrm{CFU} / \mathrm{ml}$ in DMEM medium. RAW264.7 cells or mouse peritoneal macrophages $\left(2 \times 10^{5}\right.$ cells/well $)$ in 24 -well plates were treated with or without sublancin $(25 \mu \mathrm{M})$ for 12 hours. After being washed with antibiotic-free DMEM medium, cells were incubated with MRSA ATCC43300 for 1 hour (20 bacteria/macrophage). After infection, nonadherent bacteria were washed away using PBS, and macrophages were incubated for 30 minutes (for phagocytosis) or 24 hours (for bacteria killing) in the presence of $10 \mu \mathrm{g} / \mathrm{ml}$ lysostaphin to eliminate the remaining extracellular bacteria. Intracellular bacteria were released by lysing the macrophages in $0.1 \%$ Triton $\mathrm{X}-100$, and the number was determined by plating serial dilutions of cell lysates on agar plates. The bacterial killing was expressed as percent changes in bacteria counts using the following formula: (bacterial count at 24 hours/bacterial count at 1 hour $) \times 100$.

2.7. Western Blot Analysis. The RAW264.7 cells grown in a $100 \mathrm{~mm}$ dish were treated with $100 \mu \mathrm{M}$ sublancin for the indicated time periods, or sublancin $(25,50,100$, or $200 \mu \mathrm{M}$ ) for $30 \mathrm{~min}$. Protein was extracted by incubating the RAW264.7 cells with ice-cold lysis buffer containing $150 \mathrm{mM} \mathrm{NaCl}, 1 \%$ Triton X-100, 0.5\% sodium deoxycholate, $0.1 \%$ SDS, $50 \mathrm{mM}$ Tris- $\mathrm{HCl}$ at $\mathrm{pH} 7.4$, and a proteaseinhibitor cocktail (Applygene, Beijing, China) for $30 \mathrm{~min}$. Subsequently cell extracts were centrifuged at $12,000 \times \mathrm{g}$ at $4^{\circ} \mathrm{C}$ for $10 \mathrm{~min}$. Protein containing supernatant was collected and quantified using a BCA Protein Assay Kit (Pierce, Rockford, IL, USA). Fifty $\mu$ g of protein samples was electrophoresed on SDS polyacrylamine gels and electrotransferred to polyvinylidene difluoride membranes (Millipore, Bedford, MA, USA). Membranes were blocked with $1 \times$ TBST containing 5\% of BSA (Sigma-Aldrich, St. Louis, MO) for $2 \mathrm{~h}$ at room temperature. The membranes were incubated with corresponding primary antibodies $(1: 1000$ dilution overnight at $4^{\circ} \mathrm{C}$ ) against p-p38 (Thr180/Tyr182) (Cell Signaling Technology, Cat: 4511S), p38 (Cell Signaling Technology, Cat: 8690S), p-ERK1/2 (Thr202/Tyr204) (Cell Signaling Technology, Cat: 4370S), ERK1/2 (Cell Signaling Technology, Cat: 4695S), p-JNK (Thr183/Tyr185) (Cell Signaling Technology, Cat: 4668S), JNK (Cell Signaling Technology, Cat: 9252S), p-NF- $\kappa$ B (Ser536) (Cell Signaling Technology, Cat: 3033P), NF- $\kappa \mathrm{B}$ (Cell Signaling Technology, Cat: 8242P), I $\kappa \mathrm{B}-\alpha$ (Cell Signaling Technology, Cat: 4812S), and GAPDH (Santa Cruz Biotechnology Inc., Cat: sc-25778). After the washing of membranes with $1 \times$ TBST, membranes were incubated with a secondary antibody (horseradish peroxidaseconjugated goat anti-rabbit IgG) (Huaxingbio Biotechnology, Beijing, China, Cat: HX2031) at a ratio of $1: 10,000$ dilution for $1 \mathrm{~h}$ at room temperature. The chemifluorescence was detected with the Western Blot Luminance Reagent (Applygene, Beijing, China) using an ImageQuant LAS 4000 mini system (GE Healthcare) and quantified using a gel-imaging system with ImageQuant TL Software (GE Healthcare).

2.8. Animal Experiments. Female BALB/c mice 4-6 weeks old were used for all studies. Mice were obtained from the HFK Bioscience Co. Ltd. (Beijing, China). All mice used in this study were housed in plastic cages under $12 \mathrm{~h}$ light/dark cycle and had access to food and water ad libitum. All the techniques for the care and handing of the animals in this study were approved by the China Agricultural University Institutional Animal Care and Use Committee (ID: SKLAB-B-2010-003).

2.8.1. Animal Experiment 1: Sublancin-Mediated Immune Modulation in Mice under Healthy Conditions. The mice were randomly divided into three groups: control, sublancin low-dose group $(0.3 \mathrm{mg} / \mathrm{kg}$ or $0.6 \mathrm{mg} / \mathrm{kg})$, and sublancin high-dose group $(1.0 \mathrm{mg} / \mathrm{kg}$ or $1.2 \mathrm{mg} / \mathrm{kg})$. Mice were given sublancin by gavage once a day for 28 days $(0.3 \mathrm{mg} / \mathrm{kg}$ and $1.0 \mathrm{mg} / \mathrm{kg}, n=4 /$ group $)$ or 14 days $(0.6 \mathrm{mg} / \mathrm{kg}$ and $1.2 \mathrm{mg} / \mathrm{kg}$, $n=5$ /group). The control group was orally administered with distilled water daily. Twenty-four hours after the last dose, the animals were killed and blood was withdrawn for peripheral hemogram analysis. Under an aseptic technique, a laparotomy was performed through a midline incision, and peritoneal macrophages were harvested for phagocytosis assay. The peritoneal cells and spleen were collected for culture.

2.8.2. Animal Experiment 2: In Vivo Efficacy against MRSAInduced Sublethal Infection. To study the anti-infective role of sublancin in an experimental model of MRSA-induced sublethal infection, mice were randomly allocated to one of three groups ( $n=7$ to 9/group): (i) untreated, (ii) sublancin low-dose group $(0.3 \mathrm{mg} / \mathrm{kg}$ or $0.6 \mathrm{mg} / \mathrm{kg})$, and (iii) sublancin high-dose group $(1.0 \mathrm{mg} / \mathrm{kg}$ or $1.2 \mathrm{mg} / \mathrm{kg})$. Mice were orally administered with sublancin at the indicated doses for 14 consecutive days, while the untreated mice were given distilled water during the same periods. Twenty-four hours after the last drug administration, all mice were given a sublethal dose of MRSA ATCC43300 $\left(1.0 \times 10^{7} \mathrm{CFU} / \mathrm{mouse}\right)$ intraperitoneally. Animals were euthanized 36 and 72 hours after infection and peritoneal lavage was collected in $2 \mathrm{ml}$ of cold HBSS. The staphylococcal load in the peritoneal lavage was enumerated as described previously [25]. Peritoneal macrophages were collected for red fluorescent protein- (RFP-) labeled E. coli (Thermo Fisher Scientific, Waltham, MA) phagocytosis assay. The mesenteric lymph nodes (MLNs) were excised for flow cytometry.

2.9. NK Cell Activity. The tumor cell line Yac-1 was obtained from the American Type Culture Collection (Rockville, MD). Splenocytes were collected from mice in animal experiment 1 
and cocultured with Yac-1 cells to obtain an E:T (splenocytes : Yac-1) ratio of 75:1 in V-bottomed 96-well plates. After $4 \mathrm{~h}$, cytotoxicity was determined by the lactate dehydrogenase (LDH) assay using a LDH Cytotoxicity Assay Kit (Roche, Basel, Switzerland).

2.10. Cell Culture. Single-cell suspensions from spleens of mice in animal experiment 1 were prepared passing cells through a $100 \mu \mathrm{M}$ strainer. The splenocytes were plated at a density of $1 \times 10^{6} / \mathrm{ml}$ and stimulated with $2 \mu \mathrm{g} / \mathrm{ml}$ antiCD3 and $1 \mu \mathrm{g} / \mathrm{ml}$ anti-CD28 antibodies (BD PharMingen, San Diego, CA, USA). The peritoneal macrophages from mice in animal experiment 1 were cultured in the presence of $1 \mu \mathrm{g} / \mathrm{ml}$ LPS (Sigma-Aldrich, St. Louis, MO) in DMEM at a density of $1 \times 10^{6} / \mathrm{ml}$. The cells were cultured at $37^{\circ} \mathrm{C}$ for 24 hours before supernatant collection. Supernatants from splenocyte cultures were collected and analyzed by ELISA for INF- $\gamma$. The supernatants from peritoneal macrophage cultures were analyzed for TNF- $\alpha$. All ELISA kits were purchased from eBioscience Inc. (San Diego, CA, USA).

2.11. Flow Cytometry. Cells from MLNs of mice in animal experiment 2 were stained with CD62L-PE, CD44-APC, $\mathrm{CD} 4-\mathrm{PerCP}-\mathrm{Cy} 5.5$, and CD8-PE-Cy7 at $4^{\circ} \mathrm{C}$ for 30 minutes and then analyzed by flow cytometry (Gallios; Beckman Coulter Inc., Brea, CA, USA). The antibodies were purchased from BioLegend (San Diego, CA, USA), Beijing QuantoBio Biotechnology Co. Ltd. (Beijing, China), BD PharMingen, or eBioscience Inc.

2.12. Statistical Analysis. Data are expressed as means \pm SEM and were statistically analyzed using one-way analysis of variance followed by Tukey's post hoc test (Prism Software, version 5$). P$ values $<0.05$ were taken to indicate statistical significance.

\section{Results}

3.1. Sublancin Promoted the Secretion of Cytokines and NO from RAW264.7 Cells and Mouse Peritoneal Macrophages. Activated macrophages produce cytokines such as IL-1, IL-6, and TNF- $\alpha$ and also secrete cytotoxic and inflammatory molecules such as nitric oxide (NO) [26, 27]. Hence, the effect of sublancin on cytokine production by RAW264.7 cells and mouse peritoneal macrophages (P$\mathrm{Mac}$ ) was investigated. Untreated RAW264.7 cells secreted a basal level of TNF- $\alpha$, but they secreted barely detectable amounts of IL- $1 \beta$ and IL-6 (Figure S1). The addition of sublancin significantly stimulated the production of IL$1 \beta$, IL-6, and TNF- $\alpha$ in a concentration-dependent manner $(P<0.05)$. To study the effect of sublancin on NO production in RAW264.7 cells, we measured the secretion of NO in the culture supernatant of RAW264.7 cells stimulated with sublancin alone. Compared to the control, the addition of sublancin resulted in a marked increase in $\mathrm{NO}$ production in a dose-dependent manner $(P<0.001$; Figure $\mathrm{S} 1)$. Similar results were observed in P-Mac.

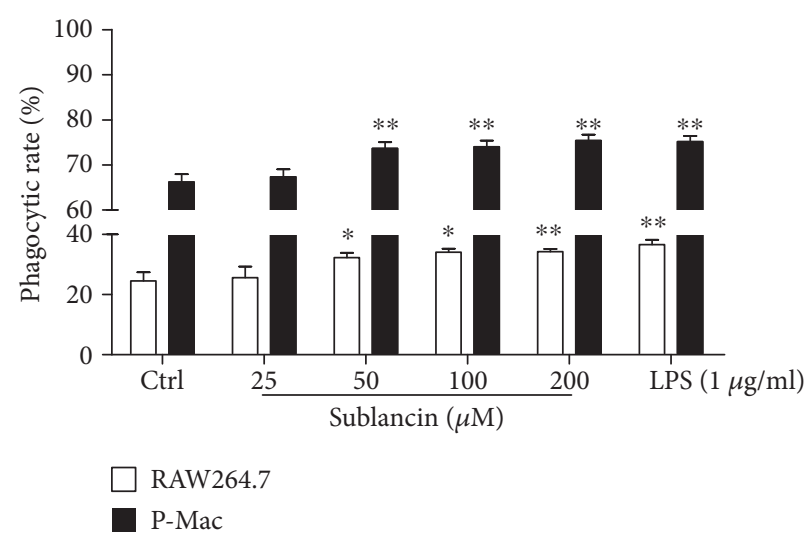

FIGURE 1: Effect of sublancin on phagocytic activity of RAW264.7 cells and mouse peritoneal macrophages (P-Mac) in vitro. RAW264.7 cells and P-Mac were treated with sublancin (0$200 \mu \mathrm{M})$ or LPS $(1 \mu \mathrm{g} / \mathrm{ml})$ for $12 \mathrm{~h}$. Phagocytic activity of macrophage cells was assessed in terms of the population of phagocytic cells relative to the total number of cells for RAW264.7 cells and P-Mac. The values are presented as mean \pm SEM $(n=6)$. Significant differences with control cells were designated as ${ }^{*} P<$ 0.05 or $^{* *} P<0.01$.

3.2. Sublancin Regulated mRNA Expression of Inflammatory Factors, Chemokines, and Costimulatory Molecules in RAW264.7 Cells and Peritoneal Macrophages. Due to the crucial role of inflammatory factors, chemokines, and costimulatory molecules in the activation and function of macrophages, we used quantitative RT-PCR to investigate the potentials for sublancin to regulate the expression of these mediators in RAW264.7 cells and P-Mac at the mRNA level. Consistent with the results at the protein level, a significant upregulation of IL- $1 \beta$, IL- 6 , TNF- $\alpha$, and iNOS mRNA expression was seen in the RAW264.7 cells or P-Mac treated with sublancin $(P<0.05)$ (Figure S2). COX-2 is an important upstream regulator for prostaglandin $\mathrm{E}_{2}$ expression. The sublancin treatments resulted in a notable increase in the mRNA expression of COX-2 compared to that of the control cells. IL- 8 and monocyte chemoattractant protein-1 (MCP-1) are the primary chemokines that recruit neutrophils and monocytes, respectively. We found that sublancin increased mRNA expression of IL-8 and MCP-1 in both RAW264.7 cells and P-Mac. B7-1 and B7-2 are two classical surface markers of activated macrophages. It was found that the expression of B7-1 and B7-2 was also increased significantly in sublancin treatments, suggesting that sublancin directly induces macrophage activation.

3.3. Influence of Sublancin on Macrophage Phagocytic Activity In Vitro. Phagocytosis is one of the primary functions of macrophages, and it is specialized in excluding foreign bodies [28]. We examined the effect of sublancin on the phagocytic uptake of fluorescent microspheres in RAW264.7 cells and peritoneal macrophages using a flow cytometer. As shown in Figure 1, sublancin stimulated the phagocytic activity of RAW264.7 cells or peritoneal macrophages compared with that of the control. 


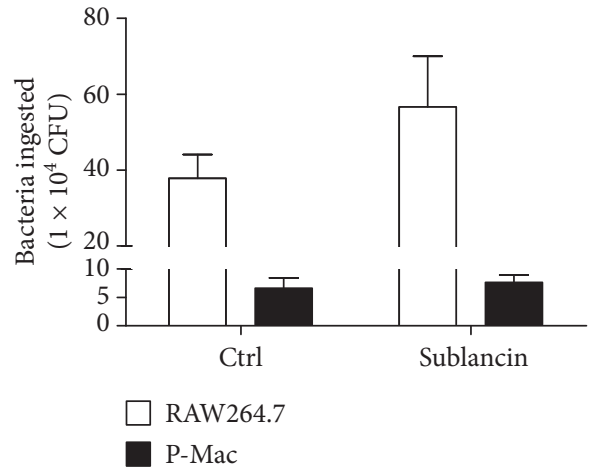

(a)

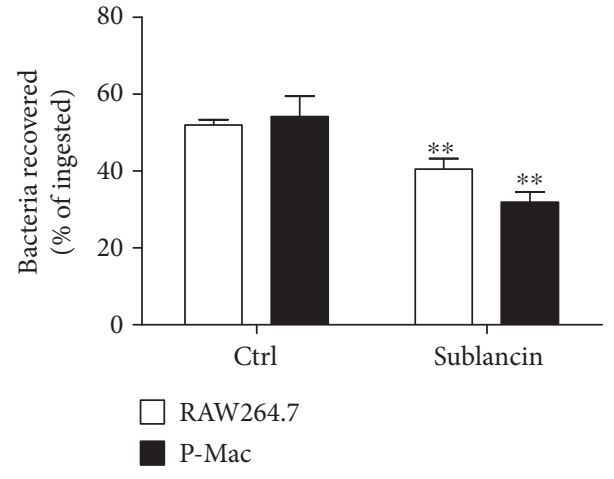

(b)

FIGURE 2: The antimicrobial peptide sublancin promoted the capacity of RAW264.7 macrophages and mouse peritoneal macrophages (P-Mac) to kill Staphylococcus aureus ATCC43300. RAW264.7 macrophages and P-Mac were cultured 12 hours with or without sublancin $(25 \mu \mathrm{M})$ and then exposed to ATCC43300 (MOI 20). Phagocytosis (a) and killing (b) of bacteria were quantified as described in Materials and Methods. Data are presented as mean \pm SEM $(n=6)$. Significant difference with control cells was designated as ${ }^{* *} P<0.01$.

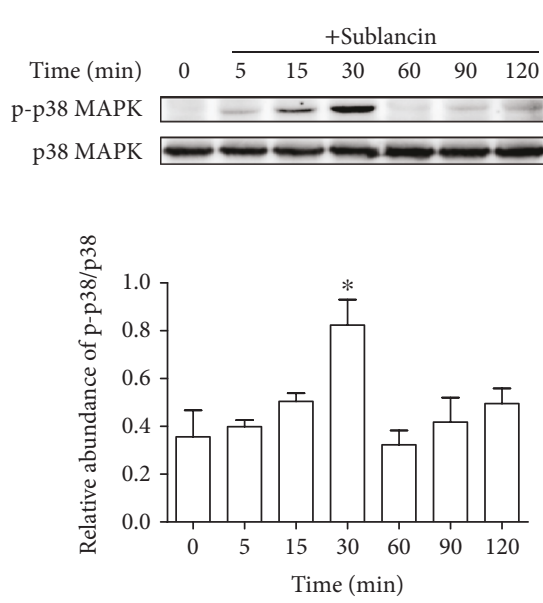

(a)
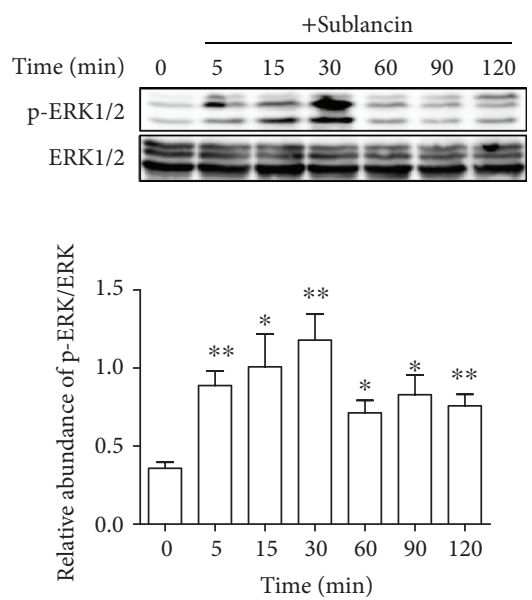

(b)

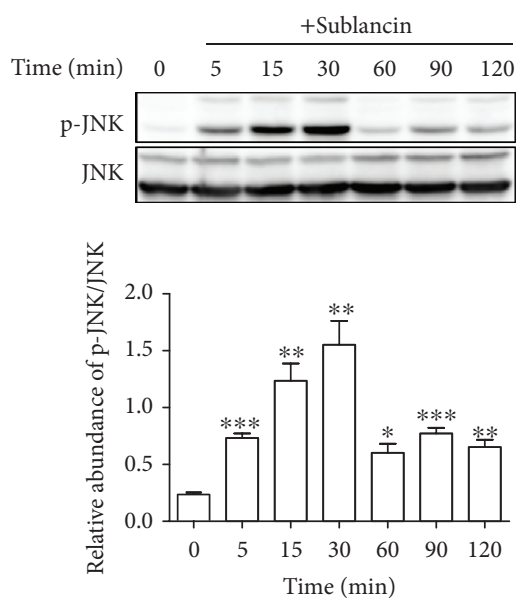

(c)

FIGURE 3: Analysis of p38, ERK, and JNK signaling pathways in RAW264.7 cells treated with sublancin for different times. RAW264.7 cells were treated with $100 \mu \mathrm{M}$ sublancin for the indicated times, and the phosphorylation of p38, ERK1/2, and JNK were detected by Western blot analysis. Representative immunoblots and quantitation of the phosphorylation abundance of p38 (a), ERK1/2 (b), and JNK (c). The values are presented as mean $\pm \operatorname{SEM}(n=3)$. Significant differences with control cells were designated as ${ }^{*} P<0.05,{ }^{* *} P<0.01$, or ${ }^{* * *} P<0.001$.

3.4. Sublancin Enhances Bactericidal Capacity of Macrophages In Vitro. Phagocytosis is the first step of the bactericidal activity of macrophages. After 1 hour, the phagocytosis of MRSA remained unchanged in RAW264.7 cells or peritoneal macrophages preincubated with $25 \mu \mathrm{M}$ sublancin. Bacterial killing by macrophages was assayed after 24 hours of incubation. We observed that a marked decline in viable bacteria occurred in sublancin-treated cells (Figure 2).

\subsection{Sublancin Activates RAW264.7 Cells Partly Depending on}

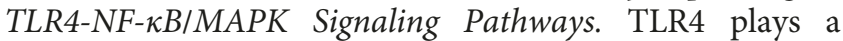
critical role in the activation of innate immune response by recognizing specific molecular patterns. To explore whether TLR4 is involved in sublancin-induced macrophage activation, RAW264.7 cells were pretreated with a TLR4 inhibitor (TAK-242). Then, the mRNA expression of cytokines was detected using quantitative RT-PCR. As shown in
Figure S3A to S3C, with the presence of the TLR4 inhibitor, the mRNA expression of IL- $1 \beta$, IL- 6 , and iNOS induced by sublancin was drastically suppressed and was significantly lower than those without an inhibitor $(P<0.001)$. The results show that the immunostimulatory effect of sublancin in macrophages is exerted probably through the activation of TLR4. The stimulation of the TLR4 signaling pathway ultimately triggers the activation of the phosphorylation of MAP kinases and transcription of NF- $\kappa \mathrm{B}$ [29]. MAPKs are well-conserved protein kinases including p38 MAP kinases, extracellular signal-regulated kinase, and JNK [30-32]. Treatment with $100 \mu \mathrm{M}$ sublancin resulted in a significant increase in the phosphorylation of all three MAPKs (p38, ERK, and JNK) and the phosphorylation peaked $30 \mathrm{~min}$ after sublancin exposure (Figure 3). We also investigated the phosphorylation status of the above mediators after treatment with sublancin at different 

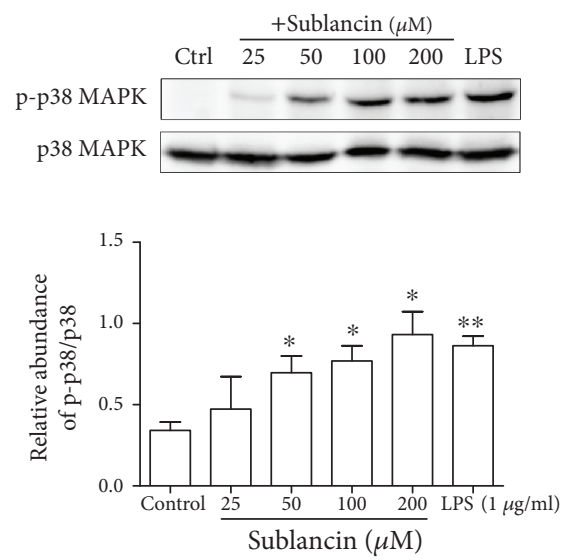

(a)
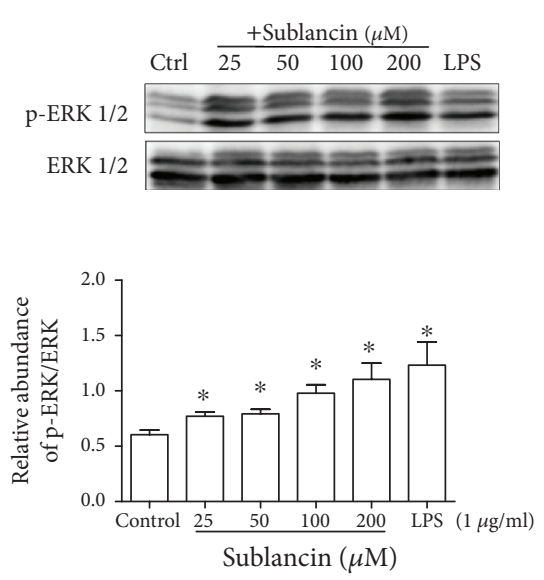

(b)
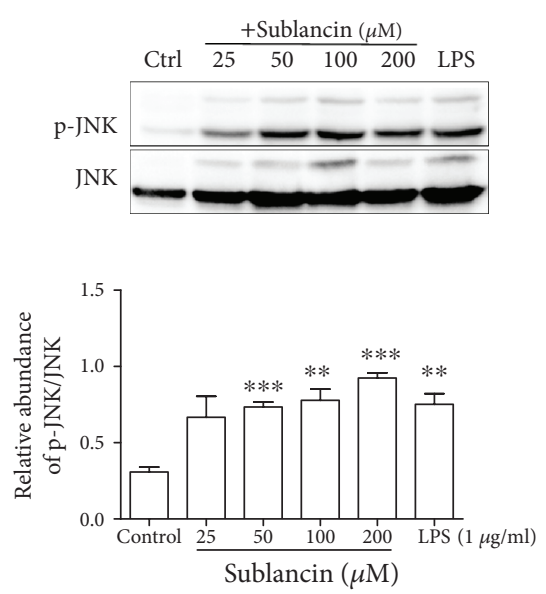

(c)
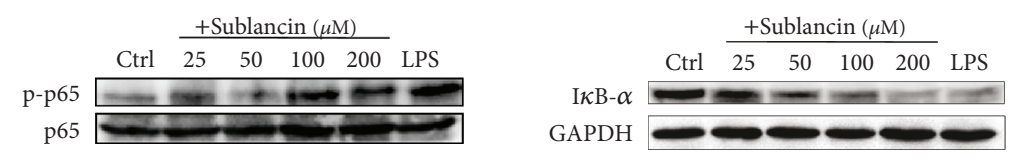

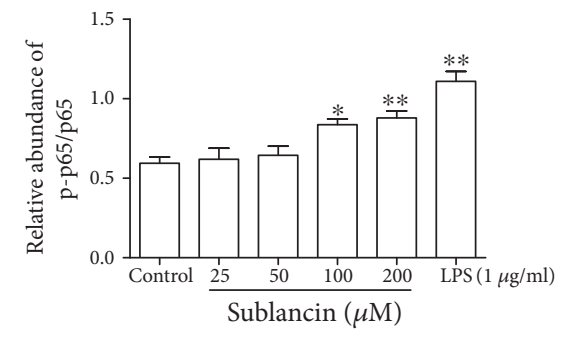

(d)

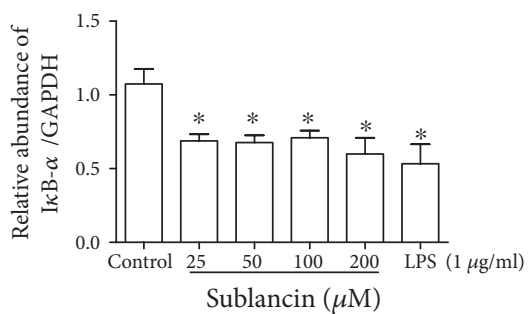

(e)

FIGURE 4: Sublancin regulates the MAPK and NF- $\kappa$ B signaling pathways in macrophages. Representative Western blots for phosphorylated p38 and total p38 (a), ERK1/2 (b), JNK (c), and p65 (d) in RAW264.7 cells treated with sublancin $(0-200 \mu \mathrm{M})$ or LPS (1 $\mu \mathrm{g} / \mathrm{ml})$ for $30 \mathrm{~min}$. Relative abundance was represented as phosphorylated protein to total protein expression. (e) Western blot analysis and quantification of I $\kappa$ B $-\alpha$ in RAW264.7 cells treated with sublancin $(0-200 \mu \mathrm{M})$ or LPS $(1 \mu \mathrm{g} / \mathrm{ml})$ for $30 \mathrm{~min}$. The values are presented as mean \pm SEM $(n=3)$. Significant differences with control cells were designated as ${ }^{*} P<0.05,{ }^{* *} P<0.01$, or ${ }^{* * *} P<0.001$.

concentrations for $30 \mathrm{~min}$. Sublancin significantly upregulated the phosphorylation of all the three MAPKs in RAW264.7 cells in a concentration-dependent manner (Figure 4). In macrophages, NF- $\kappa \mathrm{B}$ is an important regulator of immune activation through the induction of many cytokines [33]. Sublancin stimulated the phosphorylation of NF- $\kappa \mathrm{B}$ p65, while it correspondingly decreased $\mathrm{I} \kappa \mathrm{B}-\alpha$ in the cytosol (Figure 4). To further confirm whether sublancin activates macrophages through MAPK and NF- $\kappa$ B pathways, we used inhibitors to inhibit the initiation of signal transduction. Sublancin-induced mRNA expression of IL- $1 \beta$ and IL- 6 was significantly suppressed by the NF- $\kappa \mathrm{B}$ (Bay11-7082) inhibitor $(P<0.05)$ (Figures S3D, S3E). In addition, the ERK (U0126) and p38 (SB203580) inhibitors significantly exerted the inhibition of iNOS mRNA expression $(P<0.001)$ (Figure S3F). Moreover, the phosphorylation of p38 MAPK, ERK1/2, and JNK induced by sublancin was dramatically inhibited by the TLR4 inhibitor (Figure S3G). These data indicated that the activation of macrophages induced by sublancin was partly dependent on the TLR4NF- $\kappa$ B/MAPK signaling pathways.
3.6. In Vivo Sublancin-Mediated Immune Modulation. To evaluate the in vivo effect of sublancin, mice were orally administered with sublancin for the indicated time, and PMac were collected to assess phagocytosis activity and the capability of TNF- $\alpha$ production. Compared to the control group, the three levels of sublancin treatments $(1.0 \mathrm{mg} / \mathrm{kg}$ for 28 days; $0.6 \mathrm{mg} / \mathrm{kg}$ and $1.2 \mathrm{mg} / \mathrm{kg}$ for 14 days) significantly enhanced the phagocytosis activity of P-Mac (Figures 5(a) and 5(b)), which is consistent with the data of the phagocytosis activity obtained from the in vitro study. However, no significant TNF- $\alpha$ promotion was found in P$\mathrm{Mac}$ isolated from sublancin-treated mice (Figure 5(c)).

It has been reported that NK cells play a central role in the innate immune response to tumors and infections [34]. The sublancin treatment of $1.2 \mathrm{mg} / \mathrm{kg}$ had a tendency $(P=0.07)$ to promote NK cell activity compared with the control group (Figure 5(d)). Activated T cells (anti-CD3 and anti-CD28 stimulation for 24 hours) from the spleen were examined for IFN- $\gamma$ production. As shown in Figure 5(e), spleen T cells from $1.2 \mathrm{mg} / \mathrm{kg}$ sublancin-treated mice secreted more IFN- $\gamma$ than that from the control $(P<0.05)$. 


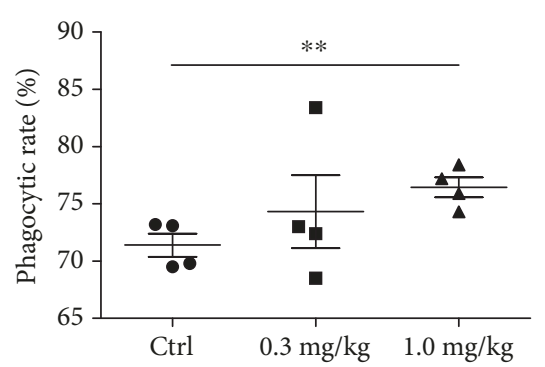

(a)

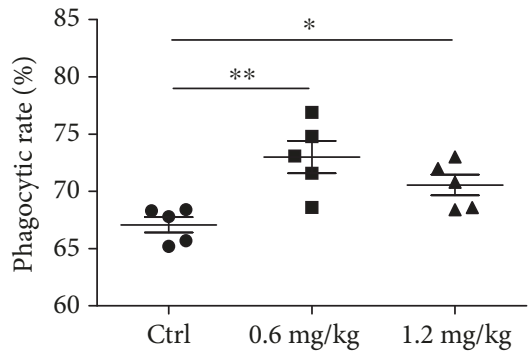

(b)

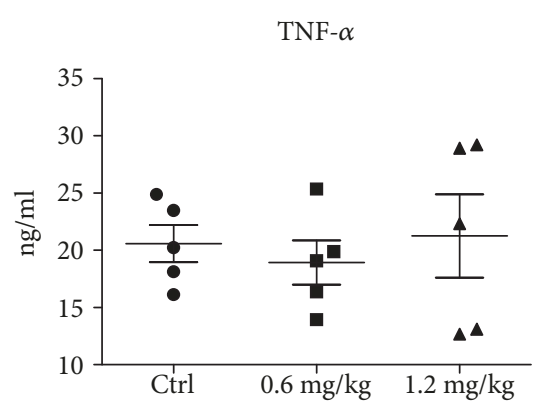

(c)

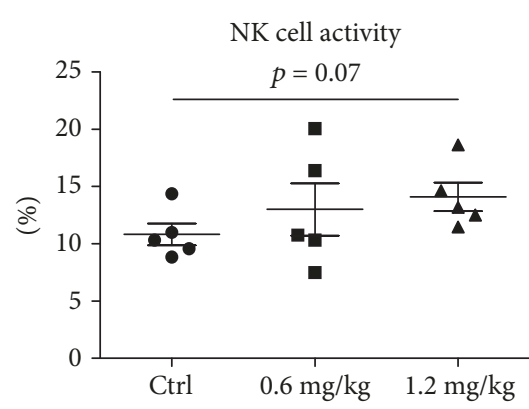

(d)

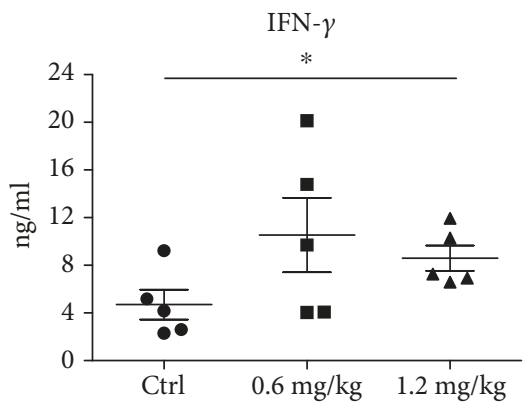

(e)

FIgURE 5: Effects of sublancin on the function of peritoneal cells and splenocytes in vivo. Sublancin enhanced the phagocytic activity of peritoneal macrophages ex vivo (a and b). Four- to six-week-old female BALB/c mice were separated into three groups: control, sublancin low-dose group $(0.3 \mathrm{mg} / \mathrm{kg}$ or $0.6 \mathrm{mg} / \mathrm{kg})$, and sublancin high-dose group $(1.0 \mathrm{mg} / \mathrm{kg}$ or $1.2 \mathrm{mg} / \mathrm{kg})$. The mice were orally administered with sublancin for 28 days $(0.3 \mathrm{mg} / \mathrm{kg}$ and $1.0 \mathrm{mg} / \mathrm{kg})$ or 14 days $(0.6 \mathrm{mg} / \mathrm{kg}$ and $1.2 \mathrm{mg} / \mathrm{kg})$. Mice in the control group were given distilled water by gavage. Peritoneal macrophages were harvested and incubated with fluorescent microspheres for the determination of phagocytic activity. (c) Comparison of TNF- $\alpha$ production in peritoneal macrophages stimulated with LPS ( $1 \mu \mathrm{g} / \mathrm{ml})$. (d) Sublancin (1.2 mg/kg) promoted a weak level of NK cell activity. Splenocytes were isolated from mice and cocultured with Yac-1 cells by a ratio (splenocytes:Yac-1) of 75:1 for $4 \mathrm{~h}$. Cytotoxicity was measured by the lactate dehydrogenase assay. (e) Comparison of IFN- $\gamma$ level in activated splenic T cells $(2 \mu \mathrm{g} / \mathrm{ml}$ anti-CD3 and $1 \mu \mathrm{g} / \mathrm{ml}$ anti-CD28 antibodies). Data shown are means \pm SEM and derived from 4 to 5 mice in each group. Significant difference with the control group were designated as ${ }^{*} P<0.05$ and ${ }^{* *} P<0.01$.

3.7. Protection of Mice from MRSA-Induced Sublethal Infection by Sublancin. Because of the potent and promising immunomodulatory property of sublancin, this peptide was tested for its anti-infective potential. Sublancin was administered by gavage daily at the indicated doses for 14 consecutive days. Twenty-four hours after the last drug administration, mice were subjected to a sublethal dose $\left(1.0 \times 10^{7} \mathrm{CFU} /\right.$ mouse $)$ of MRSA ATCC43300. As shown in Figure 6, treatment with the three sublancin levels $(0.6,1.0$, and $1.2 \mathrm{mg} / \mathrm{kg})$ tended to decrease $(P<0.1)$ the number of viable bacterial counts in the peritoneal fluid 72 hours after infection. Additionally, mice treated with $1.2 \mathrm{mg} / \mathrm{kg}$ sublancin had fewer $(P<0.05)$ viable bacterial counts in the peritoneal lavage than the control mice 36 hours after infection.

Macrophages have been shown to phagocytose and directly kill bacteria. Therefore, P-Mac were collected 36 and 72 hours after infection for the RFP-labeled Escherichia coli phagocytosis assay. Compared with the control group, the sublancin $(1.0 \mathrm{mg} / \mathrm{kg})$ treatment stimulated the phagocytic activity of P-Mac (Figure 6(c)), which may account for the decreased number of viable bacterial counts in the peritoneal lavage. As T cells, especially $\mathrm{CD} 4^{+}$and $\mathrm{CD} 8^{+}$subsets of $\mathrm{T}$ cells, play a critical role in the immune responses to specific antigenic challenges, the changes of T cells in MLNs were examined. Compared with control mice, mice treated with $1.0 \mathrm{mg} / \mathrm{kg}$ sublancin displayed a dramatic increase in the frequency of $\mathrm{CD}^{+}$and $\mathrm{CD} 8^{+} \mathrm{T}$ cells, with a corresponding increase in the frequency of naïve $\mathrm{CD} 4^{+} \mathrm{T}$ cells and memory $\mathrm{CD}^{+} \mathrm{T}$ cells (Figure 7). This difference was reflected by an increased total number of $\mathrm{CD} 8^{+} \mathrm{T}$ cells and naïve $\mathrm{CD} 4^{+} \mathrm{T}$ cells, as well as an increased number of memory $\mathrm{CD} 8^{+} \mathrm{T}$ cells and naïve $\mathrm{CD}^{+} \mathrm{T}$ cells (Figure 7). Similarly, mice treated with $1.2 \mathrm{mg} / \mathrm{kg}$ sublancin showed increased frequencies of $\mathrm{CD}^{+}(P<0.05)$ and $\mathrm{CD}^{+}(P=0.06)$ T cells 36 hours after infection (Figure 8). The frequencies of activated $\mathrm{CD} 4^{+}$, naïve $\mathrm{CD}^{+}$, and naïve $\mathrm{CD} 8^{+} \mathrm{T}$ cells were significantly increased in MLNs of $0.6 \mathrm{mg} / \mathrm{kg}$ and $1.2 \mathrm{mg} / \mathrm{kg}$ sublancin-treated mice $(P<0.05)$ (Figure 8). However, no differences in $\mathrm{T}$ cell frequency or cell number were observed in MLNs 72 hours after infection among the different treatments (Figure S4).

\section{Discussion}

Antimicrobial peptides provide immediate, effective, and nonspecific defenses against infections through direct bactericidal activity or through indirect modulation of the host defense system by enhancing immune-responsive cells [35]. 

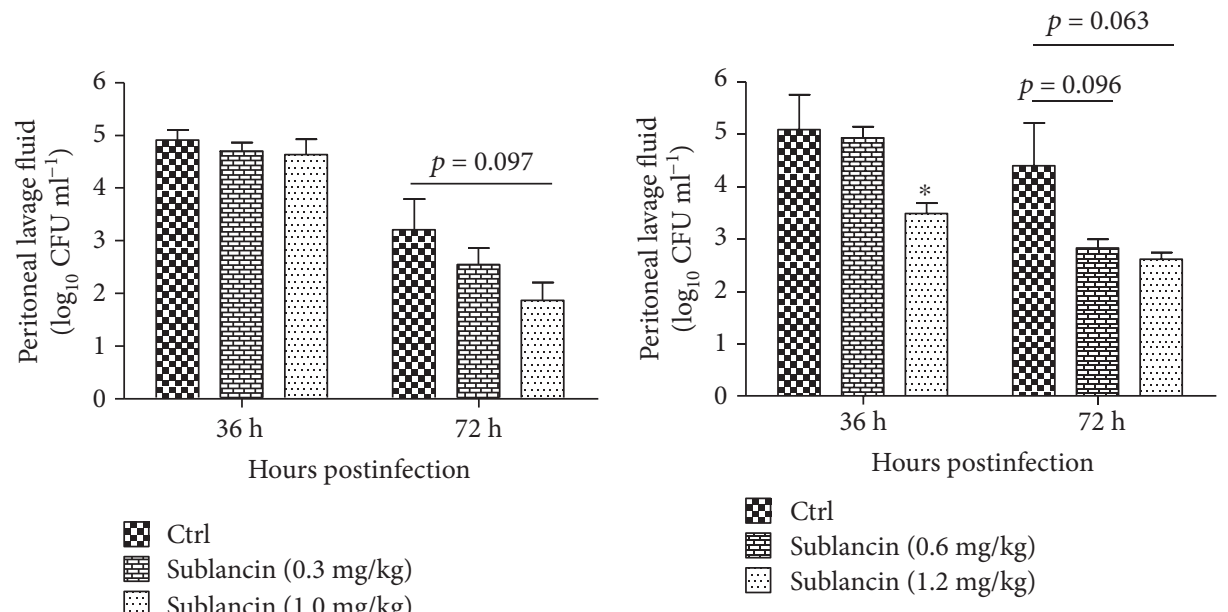

(a)

(b)
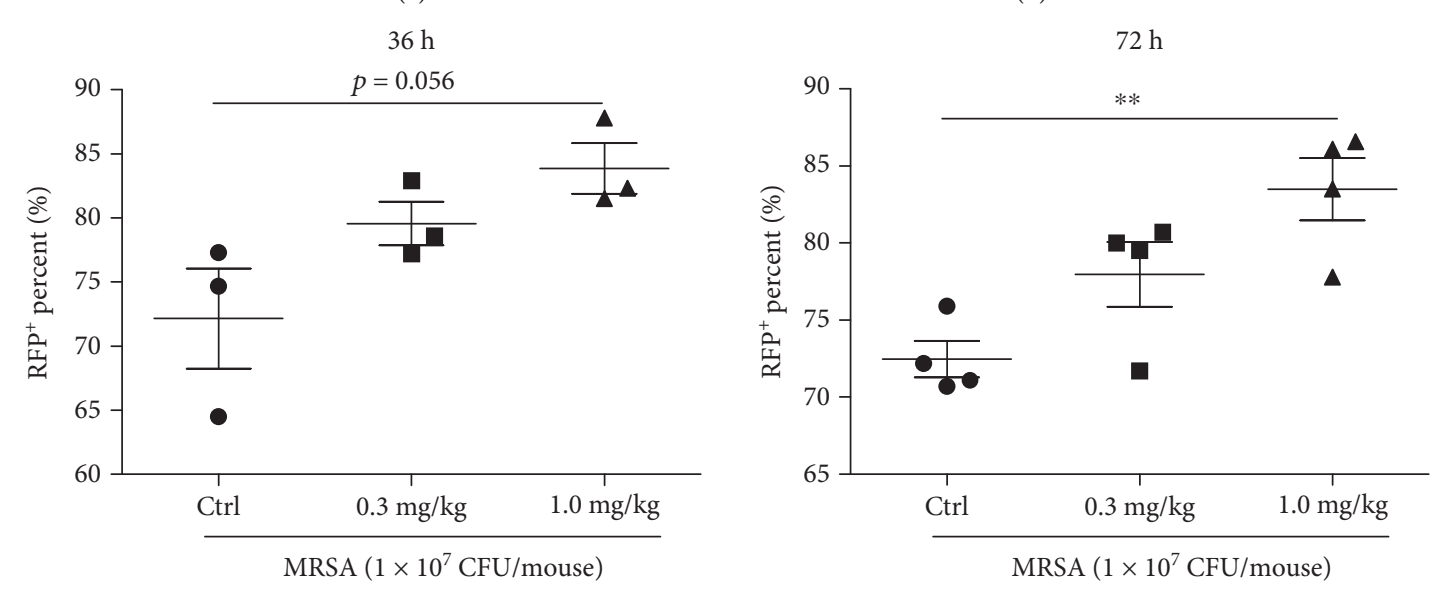

(c)

Figure 6: Efficacy of sublancin in the MRSA-induced sublethal infection model. (a) Mice were orally administered with sublancin at $0.3 \mathrm{mg} / \mathrm{kg}$ or $1.0 \mathrm{mg} / \mathrm{kg}$ once a day for 14 consecutive days before intraperitoneal inoculation of MRSA ATCC43300. The staphylococcal load in the peritoneal lavage was enumerated at 36 and $72 \mathrm{~h}$ of infection. (b) Sublancin $(0.6 \mathrm{mg} / \mathrm{kg}$ or $1.2 \mathrm{mg} / \mathrm{kg})$ was administered by gavage daily for 14 days before infection. Mice were analyzed for bacterial counts in the peritoneal lavage at 36 and $72 \mathrm{~h}$ of infection. (c) Peritoneal macrophages were collected 36 and 72 hours after infection for red fluorescent protein- (RFP-) labeled Escherichia coli phagocytosis assay. Data shown are means \pm SEM and derived from 3 to 4 mice in each group. Significant differences with the control group were designated as ${ }^{*} P<0.05$ and ${ }^{* *} P<0.01$.

Sublancin, produced by Bacillus subtilis 168, has been studied extensively for its antibacterial mechanisms [36, 37]. Following our previous studies of the anti-infective efficacy of sublancin in several in vivo infection models $[18,19]$, we examined its role and anti-infection mechanism in a mouse model of MRSA-induced sublethal infection.

Macrophage activation is the key event in innate immunity for host defense against bacterial infections, and many immunomodulatory agents activate immune responses primarily by the activation of macrophages [38, 39]. Activated macrophages are considered to be associated with the generation of IL- $1 \beta$, IL- 6 , TNF- $\alpha$, and NO. Upon stimulation by AMPs, different immune cells have been demonstrated to produce cytokines or chemokines. For example, human neutrophil peptides 1 and 3 were found to stimulate the production of IL-1, IL-4, IL-6, and TNF- $\alpha$ in monocytes [40] and MCP-1 in lung epithelial cells [41]. In addition, the AMP LL-37 was shown to increase the release of IL- 8 in airway epi- thelial cells [42]. Here, we show that sublancin stimulated both the protein and mRNA levels of IL-1 $\beta$, IL-6, TNF- $\alpha$, and NO in RAW264.7 cells and mouse peritoneal macrophages. Consistently, the mRNA expression of chemokines (such as IL-8 and MCP-1) and costimulatory molecules (B7-1 and B7-2) was also increased by sublancin in RAW264.7 cells and mouse peritoneal macrophages. These observations suggest that sublancin could directly enhance the activation of macrophages.

A critical finding in this study was that sublancin significantly enhanced the phagocytic activity of a macrophage against MRSA both in vitro and in vivo. Wan et al. in 2014 reported that LL-37 elevated bacterial phagocytosis by human macrophages [43]. Furthermore, it has also been demonstrated that human neutrophil peptides 1-3 enhance bacterial phagocytosis by macrophages [44]. Consistent with the above notions, we found that sublancin can simulate the phagocytosis of fluorescent microspheres in RAW264.7 cells 

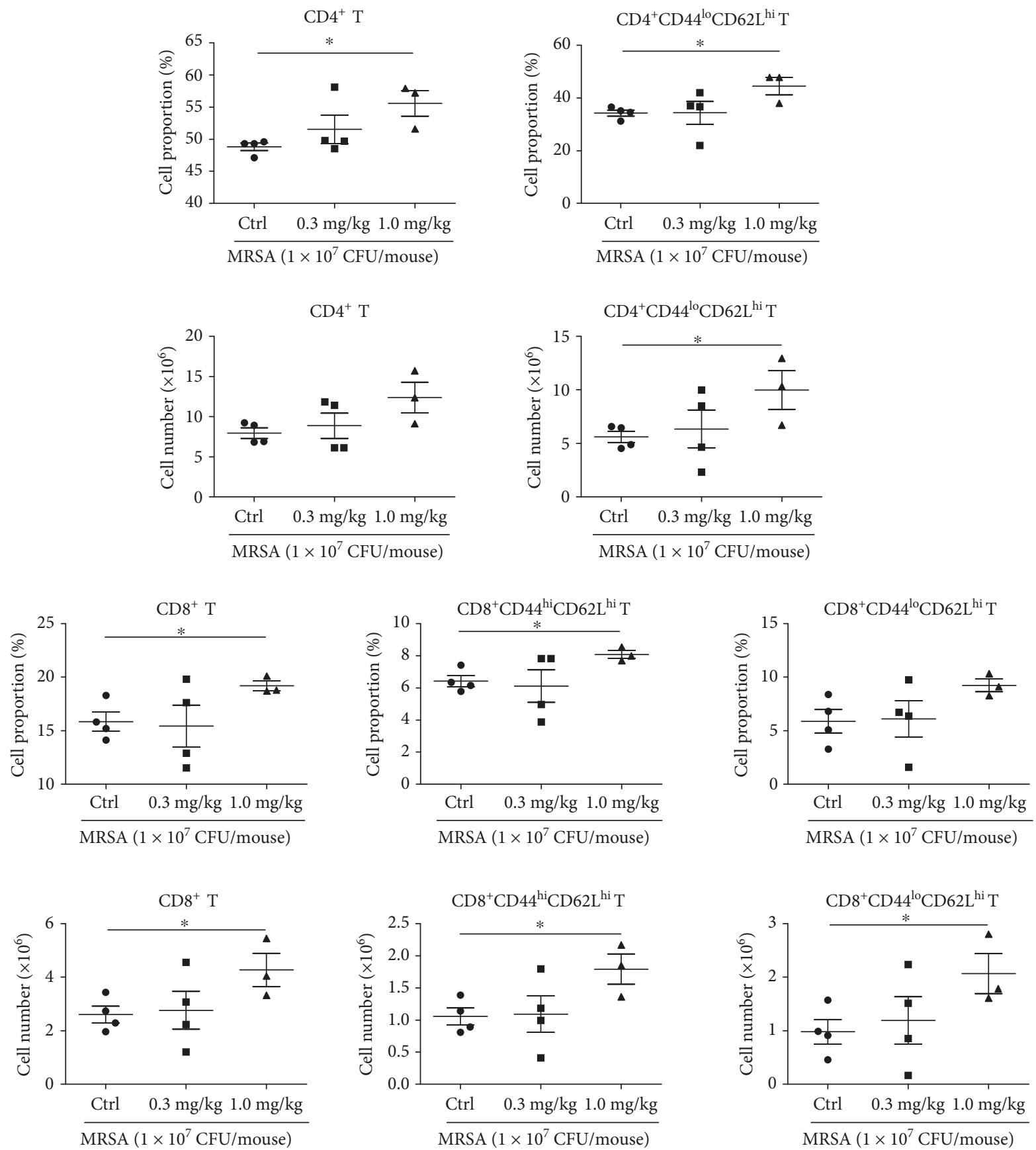

FIGURE 7: Effects of sublancin on the immune cell subset in the mesenteric lymph nodes (MLNs) of MRSA-challenged mice. Mice were orally administered with sublancin $(0.3 \mathrm{mg} / \mathrm{kg}$ or $1.0 \mathrm{mg} / \mathrm{kg})$ for 14 consecutive days before infection. Phenotypic analysis of single-cell suspensions collected from the MLNs (the MLNs were excised from the mice 36 hours after infection). The phenotype of CD $4^{+}$and CD $8^{+} \mathrm{T}$ cells was further characterized by the expression of CD44 and CD62L, cell surface receptors which are differentially expressed on memory $\left(\mathrm{CD} 44^{\mathrm{hi}} \mathrm{CD} 62 \mathrm{~L}^{\mathrm{hi}}\right)$ and naive $\left(\mathrm{CD} 44^{\mathrm{lo}} \mathrm{CD} 62 \mathrm{~L}^{\mathrm{hi}}\right) \mathrm{T}$ cell populations.

and peritoneal macrophages. Next, the effect of sublancin on the phagocytic activity was determined using mouse peritoneal macrophages ex vivo. In healthy or MRSA-challenged mice, the oral administration of sublancin enhanced the phagocytic activity of peritoneal macrophages. Mice pretreated with sublancin before the MRSA infection acquired a potent antibacterial activity. It was found that sublancin tended to decrease the bacterial burden in the peritoneal cavity. Our previous research has shown that monocytes/macrophages are pivotal for the protective effect of sublancin [20]. Therefore, we further tested whether sublancin could enhance macrophage function by the augmentation of the bacterial clearance. In the present study, we found that the preincubation of macrophages with sublancin promoted the MRSA-killing activity in macrophages. We speculate that the sublancin-enhanced microbicidal activity of 

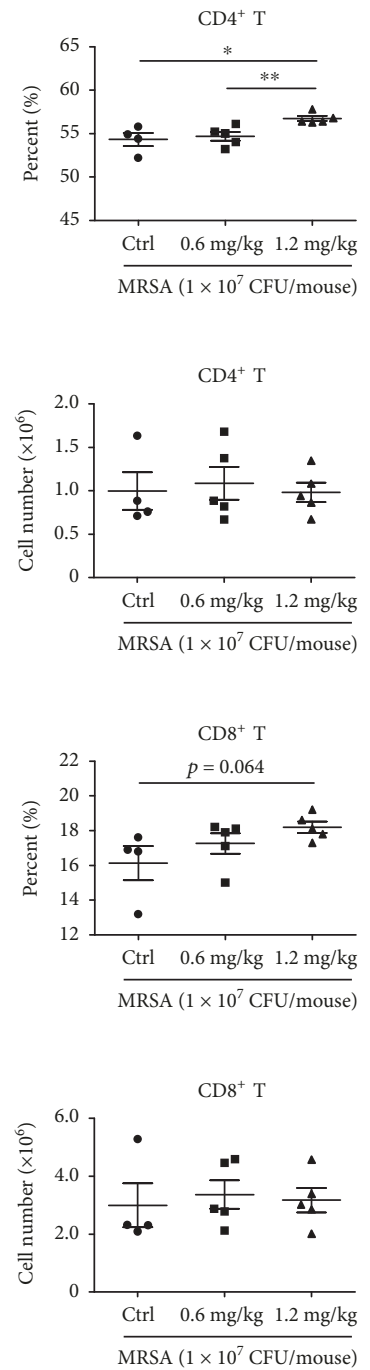

$\mathrm{CD} 4^{+} \mathrm{CD} 44^{\mathrm{hi}} \mathrm{CD} 62^{\mathrm{lo}} \mathrm{T}$
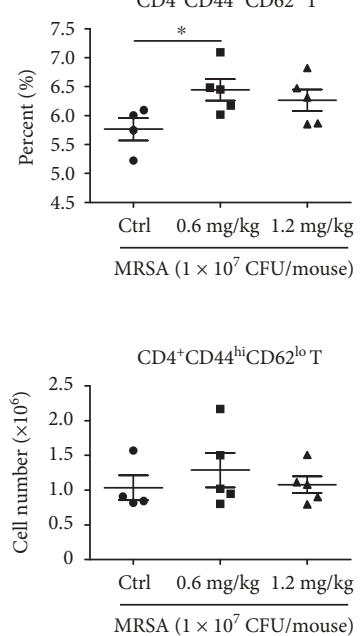

$\mathrm{CD}^{+} \mathrm{CD} 44^{\mathrm{hi}} \mathrm{CD} 62 \mathrm{~L}^{\mathrm{lo}} \mathrm{T}$
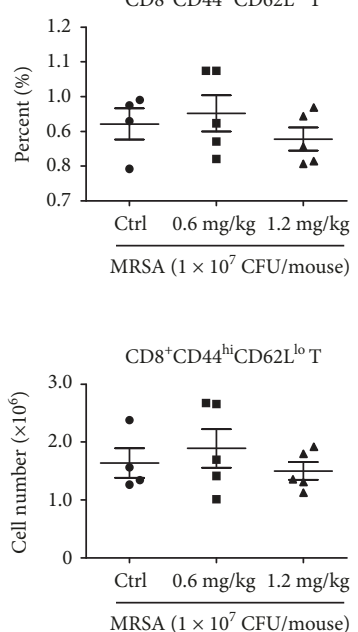
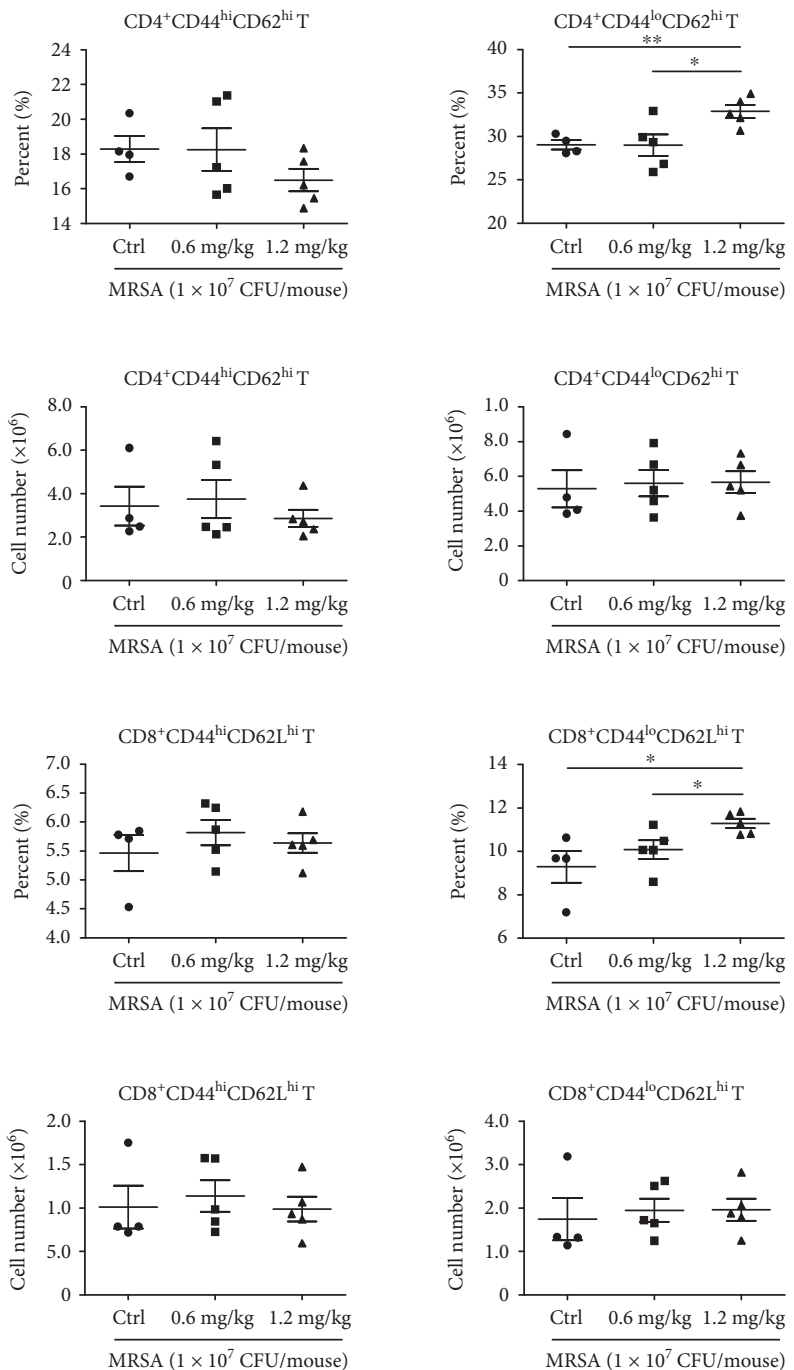

FIgURE 8: The alteration of various immune cell percentages and cell numbers in the MLNs of MRSA-challenged mice. Mice were orally administered with sublancin $(0.6 \mathrm{mg} / \mathrm{kg}$ or $1.2 \mathrm{mg} / \mathrm{kg})$ for 14 consecutive days before infection. Phenotypic analysis of single-cell suspensions collected from the MLNs (the MLNs were excised from the mice 36 hours after infection). The phenotype of CD4 ${ }^{+}$and $\mathrm{CD}^{+} \mathrm{T}$ cells was further characterized by the expression of CD44 and CD62L, cell surface receptors which are differentially expressed on activated $\left(\mathrm{CD} 44^{\text {hi }} \mathrm{CD} 62 \mathrm{~L}^{\mathrm{lo}}\right)$, memory $\left(\mathrm{CD} 44^{\mathrm{hi}} \mathrm{CD} 62 \mathrm{~L}^{\text {hi }}\right)$, and naïve $\left(\mathrm{CD} 44^{\mathrm{lo}} \mathrm{CD} 62 \mathrm{~L}^{\text {hi }}\right) \mathrm{T}$ cell populations.

macrophages may be due to the activation of macrophages induced by sublancin. Further studies are clearly warranted to elucidate the property of sublancin in facilitating bacterial clearance by macrophages.

Increasing evidence has demonstrated that signaling via TLRs leads to the production of a mass of proinflammatory mediators including cytokines (such as IL-1, IL-6, and TNF- $\alpha$ ) and NO [45]. TLR4 is known to stimulate the innate immune response through recognizing specific molecular patterns. In the study presented here, sublancinupregulated mRNA expression of IL- $1 \beta$, IL- 6 , TNF- $\alpha$, and iNOS was drastically suppressed by the TLR4 inhibitor (TAK-242), suggesting that sublancin activates macrophages probably via the TLR4 signaling pathway. It is well known that $\mathrm{NF}-\kappa \mathrm{B}$ and MAPKs are involved in regulating cytokine release via the phosphorylation of transcription factors $[46,47]$. We found that sublancin induced the phosphorylation of the three MAPKs (p38 MAPK, ERK1/2, and JNK) in
RAW264.7 macrophages. In addition, both NF- $\kappa \mathrm{B}$ p65 and $\mathrm{I} \kappa \mathrm{B}-\alpha$ were responsive to sublancin stimulation by enhancing the phosphorylation of NF- $\kappa \mathrm{B}$ p65 and the $\mathrm{I} \kappa \mathrm{B}-\alpha$ degradation, indicating that NF- $\kappa \mathrm{B}$ and MAPK signaling pathways were responsible for sublancin-induced macrophage activation. Furthermore, sublancin-induced mRNA expression of iNOS was significantly inhibited by ERK (U0126) and p38 (SB203580) inhibitors. The NF- $\kappa \mathrm{B}$ (Bay11-7082) inhibitor also decreased the mRNA expression of IL- $1 \beta$ and IL- 6 in RAW264.7 macrophages stimulated with sublancin. These observations highlight the prominent role for the ERK1/2, p38, and NF- $\kappa \mathrm{B}$ pathways in the sublancin-induced macrophage activation. Additionally, sublancin-upregulated phosphorylation of p38 MAPK, ERK1/2, and JNK was obviously depressed by the TLR4 (TAK-242) inhibitor, further confirming that sublancin acts directly on macrophages partly depending on TLR4 signaling pathways. 
The results obtained from the in vitro assays prompted us to explore the in vivo immunomodulatory properties of sublancin in mice. Firstly, the peripheral hemogram analysis from mice that were treated with sublancin $(0.3 \mathrm{mg} / \mathrm{kg}$ and $1.0 \mathrm{mg} / \mathrm{kg}$ ) for 28 days showed no disturbances in the blood parameters (data no shown), implying that sublancin did not cause apparent toxicity in vivo. IFN- $\gamma$ has been recognized as the pivotal cytokine of Th1-polarized immunity [48]. In the study presented here, sublancin enhanced the ability of spleen $\mathrm{T}$ cells to secrete INF- $\gamma$, indicating that sublancin slightly triggered the Th1 immunity response. No promotion was observed in the TNF- $\alpha$ production of $\mathrm{P}$ $\mathrm{Mac}$ isolated from sublancin-treated mice, which indicates that sublancin will not trigger an extensive inflammatory response under healthy conditions.

Importantly, treatment with sublancin protected mice from sublethal infection induced by MRSA ATCC43300. This protection was demonstrated as a significantly accelerated clearance of bacteria and was mediated partly by enhanced macrophage function. Additionally, emerging evidence also shows that $\mathrm{T}$ cell-mediated immunity is crucial to protect against $S$. aureus infection [49]. In the study presented here, sublancin stimulated a dramatic increase in the frequencies of $\mathrm{CD}^{+}$and $\mathrm{CD}^{+} \mathrm{T}$ cells in MLNs $36 \mathrm{~h}$ postinfection. It is considered that the retention of naïve $\mathrm{CD} 4^{+}$and $\mathrm{CD}^{+} \mathrm{T}$ cells reflects a better immune response $[50,51]$. In addition, it was also reported that cellular memory responses are also critical for the antistaphylococcal immunity [52]. In the study presented here, sublancin increased the frequencies of naïve $\mathrm{CD} 4^{+}$and $\mathrm{CD} 8^{+} \mathrm{T}$ cells, as well as memory $\mathrm{CD} 8^{+} \mathrm{T}$ cells in MLNs at 36 hours after infection. However, there was no significant difference in $\mathrm{T}$ cell frequency in MLNs among the different treatments at 72 hours after infection. These findings imply that sublancin could improve $\mathrm{T}$ cellmediated immunity in an early infection phase. In the present in vivo study, sublancin was given by oral administration. During the transit of this peptide through the gastrointestinal tract of mice, reduction of disulfides, loss of glucosylation, and/or attack of the peptide by endogenous proteases may modify some characteristics of mature sublancin. Accordingly, it could happen that the observed effects of sublancin in this study may be due to the action of sublancin-derived peptides or a partially modified mature sublancin.

In summary, sublancin might enhance not only $\mathrm{T}$ cellmediated immunity but also macrophage function. Our results suggest that sublancin is an excellent alternative to counter the MRSA infections and is worthy of further investigation to successfully translate sublancin to the clinic.

\section{Data Availability}

The data used to support the findings of this study are available from the corresponding author upon request.

\section{Conflicts of Interest}

The authors declare that they have no conflict of interests.

\section{Acknowledgments}

This work was supported by the Natural Science Foundation of Hubei Province (2018CFB125), the National Key Research and Development Program of China (2016YFD0501308), and the Special Fund for Agroscientific Research in the Public Interest (201403047).

\section{Supplementary Materials}

Table S1: sequence of the primers used for quantitative PCR. Figure S1: effect of sublancin on the production of cytokines (A to C) and nitric oxide (D) from RAW264.7 cells and mouse peritoneal macrophages (P-Mac). RAW264.7 cells and P-Mac were treated with sublancin $(0-200 \mu \mathrm{M})$ or LPS $(1 \mu \mathrm{g} / \mathrm{ml})$ for $24 \mathrm{~h}$. The data are expressed as mean \pm SEM $(n=6)$. Significant differences with control cells were designated as ${ }^{*} P<0.05,{ }^{* *} P<0.01$, or ${ }^{* * *} P<0.001$. Figure S2: the mRNA expression of inflammatory factors (A to $E$ ), chemokines ( $F$ and $G$ ), and costimulatory molecules ( $\mathrm{H}$ and $\mathrm{I}$ ) in RAW264.7 cells and mouse peritoneal macrophages (P-Mac) treated with sublancin. RAW264.7 cells and P-Mac were treated with sublancin $(0-200 \mu \mathrm{M})$ or LPS $(1 \mu \mathrm{g} / \mathrm{ml})$ for $12 \mathrm{~h}$. The expression of target genes was detected by realtime PCR. GAPDH was used as an internal standard for normalization. The values are presented as mean \pm SEM $(n=6)$. Significant differences with control cells were designated as ${ }^{*} P<0.05,{ }^{* *} P<0.01$, or ${ }^{* * *} P<0.001$. Figure S3: sublancin activated RAW264.7 cells through TLR4 signaling pathways. (A-C) Sublancin-mediated mRNA expression of cytokines via TLR4. RAW264.7 cells were pretreated for $3 \mathrm{~h}$ at $37^{\circ} \mathrm{C}$ with the TLR4 inhibitor TAK-242 $(20 \mu \mathrm{g} / \mathrm{ml})$ before stimulation with sublancin $(100 \mu \mathrm{M})$ for $12 \mathrm{~h}$. LPS was used as a positive control. The cell pellet was used to determine the mRNA expression of target genes by real-time PCR. Data are presented as mean \pm SEM $(n=4)$. Compared with the sublancin-treated cells, statistical significance is shown with ${ }^{* * *} P<0.001$. Compared with the LPS-treated cells, statistical

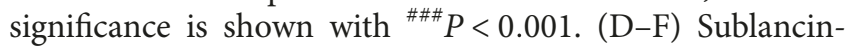
mediated mRNA expression of cytokines depends on ERK1/2, p38, and NF- $\kappa$ B activation. RAW264.7 cells were pretreated for $30 \mathrm{~min}$ with the ERK1/2 inhibitor U0126 $(10 \mu \mathrm{M})$ or the p38 inhibitor SB203580 $(20 \mu \mathrm{M})$ or pretreated for $1 \mathrm{~h}$ with the NF- $\kappa \mathrm{B}$ inhibitor Bay11-7082 $(5 \mu \mathrm{M})$ or the JNK inhibitor SP600125 $(20 \mu \mathrm{M})$ and then stimulated with sublancin $(100 \mu \mathrm{M})$. After $12 \mathrm{~h}$ of incubation, the cell pellet was used to determine the mRNA expression of target genes by real-time PCR. Data are expressed as mean \pm SEM $(n=4)$. Significant differences with the sublancin-treated cells were designated as ${ }^{*} P<0.05,{ }^{* *} P<0.01$, or ${ }^{* * *} P<0.001$. (G) Sublancin induced the phosphorylation of p38, ERK1/2, and JNK through TLR4. RAW264.7 cells were pretreated for $3 \mathrm{~h}$ with the TLR4 inhibitor TAK-242 $(20 \mu \mathrm{g} / \mathrm{ml})$ before exposure to sublancin $(100 \mu \mathrm{M})$ for $30 \mathrm{~min}$. Whole protein was extracted, and then phosphorylated p38, ERK1/2, and JNK were analyzed by Western blot. The figure shown is representative of three independent experiments. Figure S4: no difference in $\mathrm{T}$ cell frequency or cell number was observed in MLNs 72 hours after infection among the different treatments. Mice 
were orally administered with sublancin $(0.6 \mathrm{mg} / \mathrm{kg}$ or $1.2 \mathrm{mg} / \mathrm{kg}$ ) for 14 consecutive days before infection. Phenotypic analysis of single-cell suspensions collected from the MLNs (the MLNs were excised from the mice 72 hours after infection). The phenotype of $\mathrm{CD} 4^{+}$and $\mathrm{CD} 8^{+}$ $\mathrm{T}$ cells was further characterized by the expression of CD44 and CD62L, cell surface receptors which are differentially expressed on activated $\left(\mathrm{CD} 44^{\mathrm{hi}} \mathrm{CD} 62 \mathrm{~L}^{\mathrm{lo}}\right)$, memory $\left(\mathrm{CD} 44^{\mathrm{hi}} \mathrm{CD} 62 \mathrm{~L}^{\mathrm{hi}}\right)$, and naïve $\left(\mathrm{CD} 44^{\mathrm{lo}} \mathrm{CD} 62 \mathrm{~L}^{\mathrm{hi}}\right) \mathrm{T}$ cell populations. (Supplementary Materials)

\section{References}

[1] T. P. Van Boeckel, C. Brower, M. Gilbert et al., "Global trends in antimicrobial use in food animals," Proceedings of the National Academy of Sciences of the United States of America, vol. 112, no. 18, pp. 5649-5654, 2015.

[2] F. D. Lowy, "Antimicrobial resistance: the example of Staphylococcus aureus," The Journal of Clinical Investigation, vol. 111, no. 9, pp. 1265-1273, 2003.

[3] R. H. Deurenberg and E. E. Stobberingh, "The evolution of Staphylococcus aureus," Infection, Genetics and Evolution, vol. 8, no. 6, pp. 747-763, 2008.

[4] B. Spellberg, J. H. Powers, E. P. Brass, L. G. Miller, and J. E. Edwards, "Trends in antimicrobial drug development: implications for the future," Clinical Infectious Diseases, vol. 38, no. 9, pp. 1279-1286, 2004.

[5] J. Y. Ahn, J. Y. Song, Y. S. Yun, G. Jeong, and I. S. Choi, "Protection of Staphylococcus aureus-infected septic mice by suppression of early acute inflammation and enhanced antimicrobial activity by ginsan," FEMS Immunology \& Medical Microbiology, vol. 46, no. 2, pp. 187-197, 2006.

[6] Y. Nakamura, Y. Aramaki, and T. Kakiuchi, "A mouse model for postoperative fatal enteritis due to Staphylococcus infection," The Journal of Surgical Research, vol. 96, no. 1, pp. 3543, 2001.

[7] T. J. Foster, "Immune evasion by Staphylococci," Nature Reviews Microbiology, vol. 3, no. 12, pp. 948-958, 2005.

[8] M. Carini, G. Aldini, M. Orioli, A. Piccoli, G. Rossoni, and R. Maffei Facino, "Nitric oxide release and distribution following oral and intraperitoneal administration of nitroaspirin (NCX 4016) in the rat," Life Sciences, vol. 74, no. 26, pp. 3291-3305, 2004.

[9] F. Balkwill, “Tumour necrosis factor and cancer," Nature Reviews Cancer, vol. 9, no. 5, pp. 361-371, 2009.

[10] N. Fujiwara and K. Kobayashi, "Macrophages in inflammation," Current Drug Target -Inflammation \& Allergy, vol. 4, no. 3, pp. 281-286, 2005.

[11] A. Ayala and I. H. Chaudry, "Immune dysfunction in murine polymicrobial sepsis," Shock, vol. 6, Supplement, pp. S27S38, 1996.

[12] C. Munoz, J. Carlet, C. Fitting, B. Misset, J. P. Bleriot, and J. M. Cavaillon, "Dysregulation of in vitro cytokine production by monocytes during sepsis," The Journal of Clinical Investigation, vol. 88, no. 5, pp. 1747-1754, 1991.

[13] R. E. W. Hancock and M. G. Scott, "The role of antimicrobial peptides in animal defenses," Proceedings of the National Academy of Sciences of the United States of America, vol. 97, no. 16, pp. 8856-8861, 2000.

[14] H. N. Huang, C. Y. Pan, V. Rajanbabu, Y. L. Chan, C. J. Wu, and J. Y. Chen, "Modulation of immune responses by the anti- microbial peptide, epinecidin (Epi)-1, and establishment of an Epi-1-based inactivated vaccine," Biomaterials, vol. 32, no. 14, pp. 3627-3636, 2011.

[15] S. H. Paik, A. Chakicherla, and J. N. Hansen, "Identification and characterization of the structural and transporter genes for, and the chemical and biological properties of, sublancin 168, a novel lantibiotic produced by Bacillus subtilis 168," The Journal of Biological Chemistry, vol. 273, no. 36, pp. 23134-23142, 1998.

[16] S. Biswas, C. V. Garcia de Gonzalo, L. M. Repka, and W. A. van der Donk, "Structure-activity relationships of the S-linked glycocin sublancin," ACS Chemical Biology, vol. 12, no. 12, pp. 2965-2969, 2017.

[17] C. Wu, S. Biswas, C. V. Garcia de Gonzalo, and W. A. van der Donk, "Investigations into the mechanism of action of sublancin," ACS Infectious Diseases, vol. 5, no. 3, pp. 454-459, 2019.

[18] Q. Wang, X. Zeng, S. Wang et al., “The bacteriocin sublancin attenuates intestinal injury in young mice infected with Staphylococcus aureus," The Anatomical Record, vol. 297, no. 8, pp. 1454-1461, 2014.

[19] S. Wang, X. F. Zeng, Q. W. Wang et al., "The antimicrobial peptide sublancin ameliorates necrotic enteritis induced by Clostridium perfringens in broilers," Journal of Animal Science, vol. 93, no. 10, pp. 4750-4760, 2015.

[20] S. Wang, Q. Wang, X. Zeng et al., "Use of the antimicrobial peptide sublancin with combined antibacterial and immunomodulatory activities to protect against methicillinresistant Staphylococcus aureus infection in mice," Journal of Agricultural and Food Chemistry, vol. 65, no. 39, pp. 8595-8605, 2017.

[21] M. Velasco, M. J. Diaz-Guerra, P. Diaz-Achirica, D. Andreu, L. Rivas, and L. Boscá, "Macrophage triggering with cecropin A and melittin-derived peptides induces type II nitric oxide synthase expression," Journal of Immunology, vol. 158, no. 9, pp. 4437-4443, 1997.

[22] S. Wang, S. Huang, Q. Ye et al., "Prevention of cyclophosphamide-induced immunosuppression in mice with the antimicrobial peptide sublancin," Journal of Immunology Research, vol. 2018, Article ID 4353580, 11 pages, 2018.

[23] A. B. N. Putra, H. Morishige, S. Nishimoto et al., "Effect of collagens from jellyfish and bovine Achilles tendon on the activity of J774.1 and mouse peritoneal macrophage cells," Journal of Functional Foods, vol. 4, no. 2, pp. 504-512, 2012.

[24] K. J. Livak and T. D. Schmittgen, "Analysis of relative gene expression data using real-time quantitative PCR and the $2^{-\Delta \Delta \mathrm{CT}}$ method," Methods, vol. 25, no. 4, pp. 402-408, 2001.

[25] S.-A. Li, W.-H. Lee, and Y. Zhang, "Efficacy of OH-CATH30 and Its Analogs against Drug-Resistant BacteriaIn Vitroand in Mouse Models," Antimicrobial Agents and Chemotherapy, vol. 56, no. 6, pp. 3309-3317, 2012.

[26] P. J. Duerksen-Hughes, D. B. Day, S. M. Laster, N. A. Zachariades, L. Aquino, and L. R. Gooding, "Both tumor necrosis factor and nitric oxide participate in lysis of simian virus 40-transformed cells by activated macrophages," The Journal of Immunology, vol. 149, no. 6, pp. 2114-2122, 1992.

[27] C. F. Nathan, "Secretory products of macrophages," The Journal of Clinical Investigation, vol. 79, no. 2, pp. 319-326, 1987.

[28] M. Benoit, B. Desnues, and J. L. Mege, "Macrophage polarization in bacterial infections," Journal of Immunology, vol. 181, no. 6, pp. 3733-3739, 2008. 
[29] B. W. Jones, T. K. Means, K. A. Heldwein et al., "Different Tolllike receptor agonists induce distinct macrophage responses," Journal of Leukocyte Biology, vol. 69, no. 6, pp. 1036-1044, 2001.

[30] C. R. Weston and R. J. Davis, "The JNK signal transduction pathway," Current Opinion in Genetics \& Development, vol. 12, no. 1, pp. 14-21, 2002.

[31] A. R. Nebreda and A. Porras, "p38 MAP kinases: beyond the stress response," Trends in Biochemical Sciences, vol. 25, no. 6, pp. 257-260, 2000.

[32] T. P. Garrington and G. L. Johnson, "Organization and regulation of mitogen-activated protein kinase signaling pathways," Current Opinion in Cell Biology, vol. 11, no. 2, pp. 211-218, 1999.

[33] E. B. Kopp and S. Ghosh, "NF- $\kappa$ B and rel proteins in innate immunity," Advances in Immunology, vol. 58, pp. 1-27, 1995.

[34] G. Alter, J. M. Malenfant, and M. Altfeld, "CD107a as a functional marker for the identification of natural killer cell activity," Journal of Immunological Methods, vol. 294, no. 1-2, pp. 15-22, 2004.

[35] O. N. Silva, C. de la Fuente-Núñez, E. F. Haney et al., “An antiinfective synthetic peptide with dual antimicrobial and immunomodulatory activities," Scientific Reports, vol. 6, no. 1, 2016.

[36] T. R. H. M. Kouwen, E. N. Trip, E. L. Denham, M. J. J. B. Sibbald, J. Y. F. Dubois, and J. M. van Dijl, "The large mechanosensitive channel MscL determines bacterial susceptibility to the bacteriocin sublancin 168," Antimicrobial Agents and Chemotherapy, vol. 53, no. 11, pp. 4702-4711, 2009.

[37] C. V. Garcia De Gonzalo, E. L. Denham, R. A. T. Mars, J. Stülke, W. A. van der Donk, and J. M. van Dijl, "The phosphoenolpyruvate:sugar phosphotransferase system is involved in sensitivity to the glucosylated bacteriocin sublancin," Antimicrobial Agents and Chemotherapy, vol. 59, no. 11, pp. 6844-6854, 2015.

[38] K. Y. Lee and Y. J. Jeon, "Macrophage activation by polysaccharide isolated from Astragalus membranaceus," International Immunopharmacology, vol. 5, no. 7-8, pp. 1225-1233, 2005.

[39] H. Gao, G. Y. Li, J. Huang et al., "Protective effects of Zhuyeqing liquor on the immune function of normal and immunosuppressed mice in vivo," BMC Complementary and Alternative Medicine, vol. 13, no. 1, 2013.

[40] Y. V. Chaly, E. M. Paleolog, T. S. Kolesnikova, I. I. Tikhonov, E. V. Petratchenko, and N. N. Voitenok, "Human neutrophil $\alpha$-defensin modulates cytokine production in human monocytes and adhesion molecule expression in endothelial cells," European Cytokine Network, vol. 11, no. 2, pp. 257-266, 2000.

[41] H. Zhang, G. Porro, N. Orzech, B. Mullen, M. Liu, and A. S. Slutsky, "Neutrophil defensins mediate acute inflammatory response and lung dysfunction in dose-related fashion," American Journal of Physiology-Lung Cellular and Molecular Physiology, vol. 280, no. 5, pp. L947-L954, 2001.

[42] G. S. Tjabringa, J. Aarbiou, D. K. Ninaber et al., "The antimicrobial peptide LL-37 activates innate immunity at the airway epithelial surface by transactivation of the epidermal growth factor receptor," Journal of Immunology, vol. 171, no. 12, pp. 6690-6696, 2003.

[43] M. Wan, A. M. van der Does, X. Tang, L. Lindbom, B. Agerberth, and J. Z. Haeggstrom, "Antimicrobial peptide LL-37 promotes bacterial phagocytosis by human macro- phages," Journal of Leukocyte Biology, vol. 95, no. 6, pp. 971981, 2014.

[44] O. Soehnlein, Y. Kai-Larsen, R. Frithiof et al., "Neutrophil primary granule proteins HBP and HNP1-3 boost bacterial phagocytosis by human and murine macrophages," The Journal of Clinical Investigation, vol. 118, no. 10, pp. 3491-3502, 2008.

[45] S. B. Mizel, A. N. Honko, M. A. Moors, P. S. Smith, and A. P. West, "Induction of macrophage nitric oxide production by Gram-negative flagellin involves signaling via heteromeric Toll-like receptor 5/Toll-like receptor 4 complexes," Journal of Immunology, vol. 170, no. 12, pp. 6217-6223, 2003.

[46] G. L. Johnson and R. Lapadat, "Mitogen-activated protein kinase pathways mediated by ERK, JNK, and p38 protein kinases," Science, vol. 298, no. 5600, pp. 1911-1912, 2002.

[47] L. Ashall, C. A. Horton, D. E. Nelson et al., "Pulsatile stimulation determines timing and specificity of NF- $\kappa \mathrm{B}$-dependent transcription," Science, vol. 324, no. 5924, pp. 242-246, 2009.

[48] A. Nijnik, J. Pistolic, A. Wyatt, S. Tam, and R. E. W. Hancock, "Human cathelicidin peptide LL-37 modulates the effects of IFN- $\gamma$ on APCs," Journal of Immunology, vol. 183, no. 9, pp. 5788-5798, 2009.

[49] B. Spellberg and R. Daum, "Development of a vaccine against Staphylococcus aureus," Seminars in Immunopathology, vol. 34, no. 2, pp. 335-348, 2012.

[50] N. L. La Gruta and P. G. Thomas, "Interrogating the relationship between naïve and immune antiviral T cell repertoires," Current Opinion in Virology, vol. 3, no. 4, pp. 447-451, 2013.

[51] W. Tinago, E. Coghlan, A. Macken et al., "Clinical, immunological and treatment-related factors associated with normalised $\mathrm{CD}^{+} / \mathrm{CD}^{+}$T-cell ratio: effect of naive and memory T-cell subsets," PLoS One, vol. 9, no. 5, p. e97011, 2014.

[52] A. F. Brown, A. G. Murphy, S. J. Lalor et al., "Memory Th1 cells are protective in invasive Staphylococcus aureus infection," PLOS Pathogens, vol. 11, no. 11, 2015. 


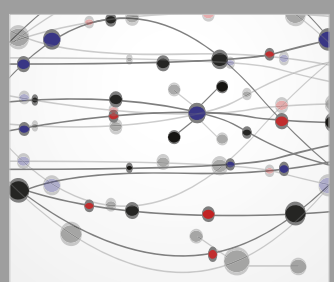

The Scientific World Journal
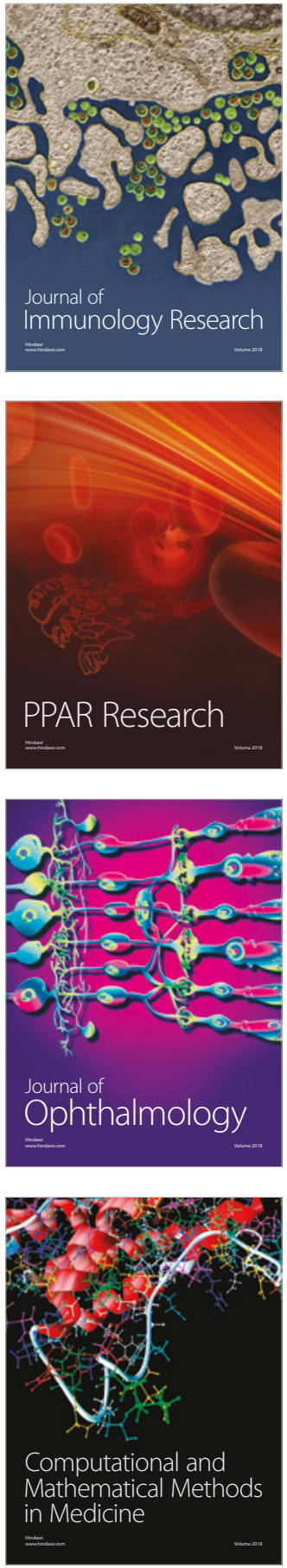

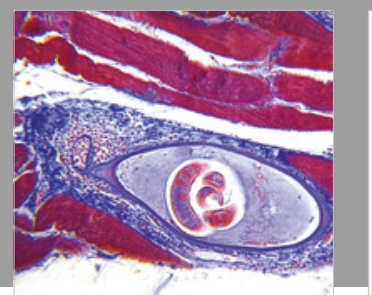

Gastroenterology Research and Practice

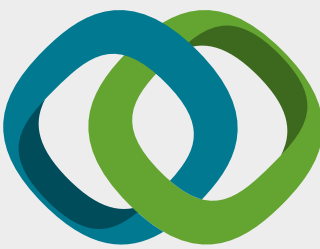

\section{Hindawi}

Submit your manuscripts at

www.hindawi.com
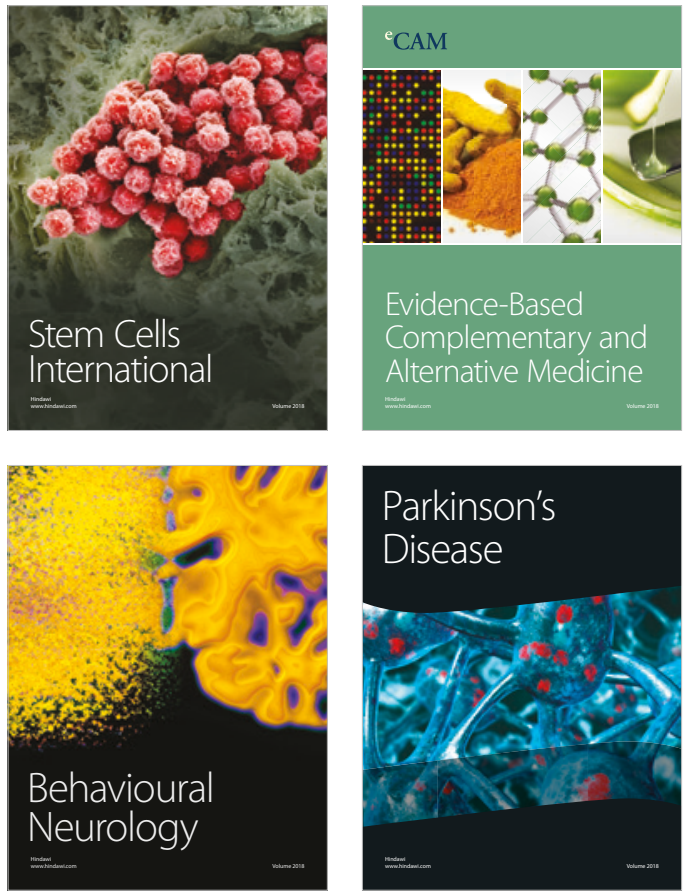

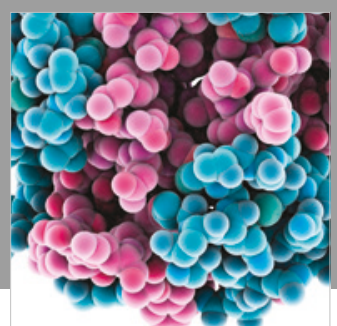

ournal of

Diabetes Research

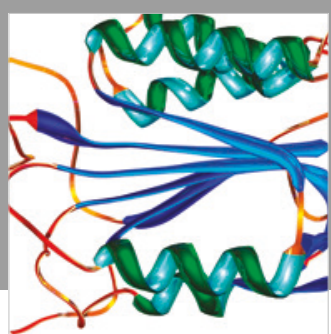

Disease Markers
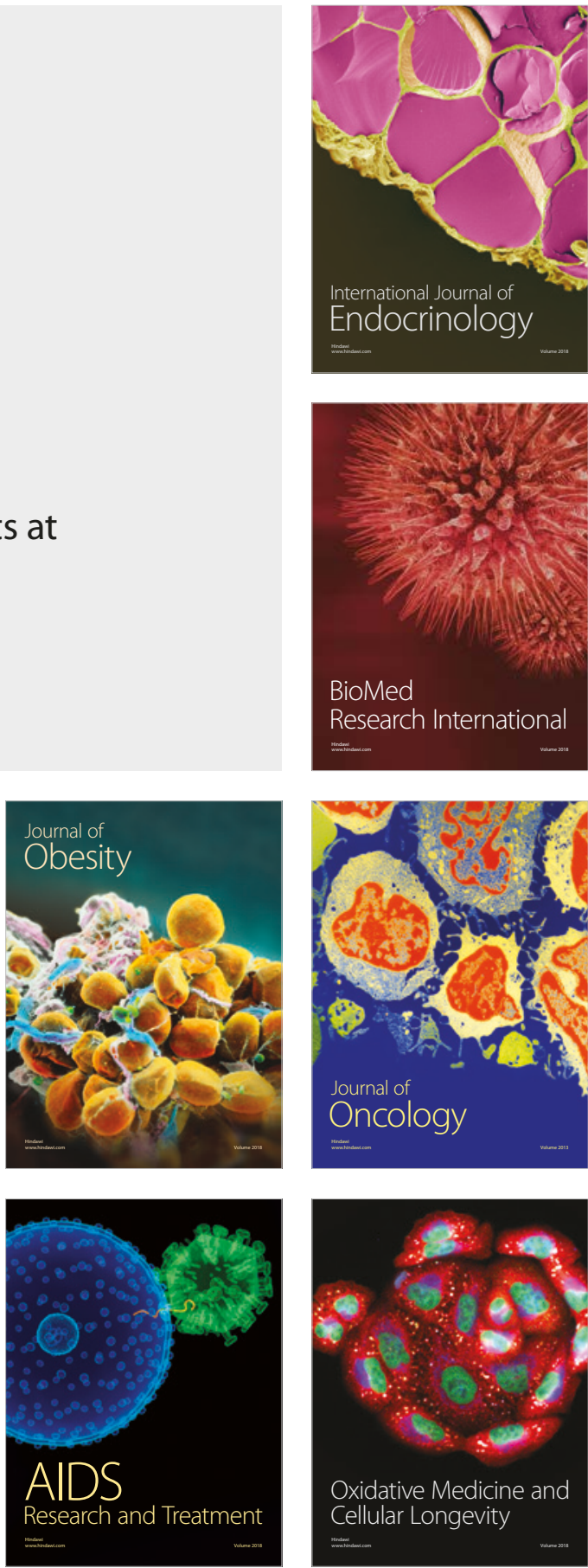